\title{
Agonist- and Voltage-Gated Calcium Entry in Cultured Mouse Spinal Cord Neurons Under Voltage Clamp Measured Using Arsenazo III
}

\author{
Mark L. Mayer, ${ }^{1}$ Amy B. MacDermott, ${ }^{2 . a}$ Gary L. Westbrook, ${ }^{1}$ Stephen J. Smith, ${ }^{3}$ and Jeffery L. Barker ${ }^{2}$ \\ 'Laboratory of Developmental Neurobiology, NICHD, and 'Laboratory of Neurophysiology, NINCDS, NIH, Bethesda, \\ Maryland 20892, and ${ }^{3}$ Section of Molecular Neurobiology, Howard Hughes Medical Institute, Yale University School of \\ Medicine, New Haven, Connecticut 06510
}

Spinal cord neurons in dissociated cell culture were loaded with the calcium indicator arsenazo III using the whole-cell patch-clamp recording technique. Under voltage-clamp, depolarizing voltage steps evoked transient increases in absorbance at $660 \mathrm{~nm}$, with no change at $570 \mathrm{~nm}$, the isosbestic wavelength for calcium-arsenazo III complexes. The optical response occurred with a threshold depolarization to -30 $\mathrm{mV}$, peaked at $+10 \mathrm{mV}$, and decreased with further depolarization, consistent with an elevation of cytoplasmic free calcium resulting from $\mathrm{Ca}^{2+}$ flux through voltage-dependent calcium channels. Inward current responses to the excitatory amino acids $\boldsymbol{N}$-methyl-D-aspartic acid (NMDA) and L-glutamate were also accompanied by calcium transients; these were dose-dependent, varied with the driving force for inward current, and were blocked by extracellular $\mathrm{Mg}^{2+}$ in a voltage-dependent manner, suggesting $\mathrm{Ca}^{2+}$ flux through NMDA-receptor channels. Responses to kainate, quisqualate, and GABA were not accompanied by comparable calcium transients. [ $\left.\mathrm{Ca}^{2+}\right]_{1}$ transients evoked by depolarizing voltage steps were of maximal amplitude at the start of recording and declined with time, reflecting rundown of voltage-dependent calcium channels. In contrast, $\left[\mathrm{Ca}^{2+}\right]_{1}$ transients evoked by NMDA gradually increased in amplitude during periods of whole-cell recording lasting 1-2 hr. Procedures resulting in loading of the neuron with $\mathrm{Ca}^{2+}$ accelerated the increase in amplitude of $\left[\mathrm{Ca}^{2+}\right]_{i}$ transients evoked by NMDA, but slowed the decay of $\left[\mathrm{Ca}^{2+}\right]_{i}$ transients evoked by voltage steps. Our results provide evidence for 2 independent sources of transmembrane $\mathrm{Ca}^{2+}$ flux in vertebrate neurons, through voltage-gated calcium channels and through NMDA-receptor channels. The $\mathrm{Ca}^{2+}$ flux gated by NMDA-receptor-specific agonists may play a role in synaptic plasticity, in regulating excitability, and in the excitotoxic response to excitatory amino acids.

Transient increases in cytoplasmic calcium ion activity regulate many cellular processes. In nerve cells, calcium entry through voltage-dependent calcium channels underlies the rapid exo-

\footnotetext{
Received Dec. 12, 1986; revised Mar. 12, 1987; accepted Apr. 7, 1987.

We thank Sandy Fitzgerald for preparation of cell cultures, Drs. J. Russell and J. Garbern for use of $\mathrm{Ca}^{2+}$-sensitive electrodes and a spectrophotometer used to measure the absorbance spectrum of arsenazo III in vitro, and Dr. Phillip G. Nelson for his continued support.

Correspondence should be addressed to Mark L. Mayer, Ph.D., Building 36, Room 2A21, National Institutes of Health, Bethesda, MD 20892.

a Present address: Howard Hughes Medical Institute, Columbia University, CPS, 722 West 168th Street, New York, NY 10032.

Copyright (C) 1987 Society for Neuroscience $0270-6474 / 87 / 103230-15 \$ 02.00 / 0$
}

cytotic release of neurotransmitter during synaptic transmission (Kat7 and Miledi, 1965, 1967). Calcium ions also act as second messengers to regulate the activity of other ion channels, as during the burst generation of action potentials in molluscan neurons (Gorman et al., 1981). A mechanism of this general type is likely to be important in regulating burst activity in many other excitable cells; for example, pacemaker-like motor activity in lamprey spinal motoneurons shows a clear dependence on extracellular calcium separate from any effect on transmitter release (Grillner and Wallén, 1985). An elevation of cytoplasmic free calcium has also been suggested as acting as a signal for the induction of long-term potentiation (LTP), a form of synaptic plasticity well characterized in hippocampal structures and associated with a stable increase in the efficacy of excitatory synaptic transmission (Dunwiddie and Lynch, 1979; Wigström et al., 1979; Turner et al., 1982; Lynch et al., 1983). In addition, elevation of cytoplasmic free calcium above physiological values is believed to occur during cerebral anoxia, hypoglycemia, or amino acid-evoked excitotoxicity, leading to neuronal cell loss and degeneration in sensitive structures (Choi, 1985; Garthwaite et al., 1986; Rothman and Olney, 1986). The source of calcium regulating these latter processes is unclear.

Elevation of cyloplasmic free calcium can, in principle, occur via 3 major mechanisms: entry of calcium through depolarization-activated, calcium-selective ion channels in the plasma membrane; entry of calcium through agonist-activated ion channels, also in the plasma membrane; or release of calcium from intracellular stores such as the endoplasmic reticulum. The ion channels activated during fast excitatory synaptic transmission, both at the neuromuscular junction and in the vertebrate CNS, have reversal potentials close to zero $\mathrm{mV}$ (Fatt and Katz, 1951; Engberg and Marshall, 1979; Brown and Johnston, 1983), and in the case of nicotinic acetylcholine receptors are generally believed to be cation-selective, with poor discrimination between monovalent cations (Takeuchi and Takeuchi, 1960; Adams et al., 1980) and only a low permeability to calcium (Gage and Van Helden, 1979; Lewis, 1979). Thus, by analogy with the neuromuscular junction, calcium influx through voltage-dependent, calcium-selective channels is generally believed to be the major source of activity-dependent increases in cytoplasmic free calcium in nerve cells. However, few experiments have examined this directly.

In the vertebrate CNS, it now seems likely that dicarboxylic amino acids, probably L-glutamate and L-aspartate, act as fast excitatory synaptic transmitters at both spinal and supraspinal sites (Mayer and Westbrook, 1987a). Vertebrate neurons express multiple receptors for excitatory amino acids; 3 subtypes have 
been identified by the use of selective agonists and antagonists: kainate, $N$-methyl-D-aspartate (NMDA), and quisqualate (Watkins and Evans, 1981). In sensitive pathways, fast excitatory synaptic potentials are blocked by nonselective excitatory amino acid antagonists such as $\gamma$-D-glutamylglycine, kynurenic acid, and cis-2,3-piperidine dicarboxylic acid, which act at all 3 receptor subtypes, whereas selective NMDA-receptor antagonists such as 2-amino-5-phosphonovaleric acid (AP5) do not antagonize fast EPSPs (for a review, see Mayer and Westbrook, 1987a). This suggests that quisqualate or kainate receptors are selectively activated during fast excitatory transmission in the vertebrate CNS. However, recent experiments have shown AP5-sensitive components of EPSP in spinal, hippocampal, and neocortical neurons (Dale and Roberts, 1985; Thomson et al., 1985; Wigström et al., 1985; Forsythe and Westbrook, 1986; Hablitz and Langmoen, 1986; Thomson 1986); such NMDA-receptor-mediated synaptic potentials are of longer duration and slower rise time than the fast component mediated by kainate/quisqualate receptors, and thus contribute little to the peak of the EPSP.

However, NMDA-receptor-mediated EPSPs may act to modulate excitability. For example, NMDA-receptor antagonists block LTP in the Schaffer collateral/commissural to CA1 and the commissural to CA3 pathways (Collingridge et al., 1983; Harris et al., 1984; Wigström and Gustafsson, 1984; Harris and Cotman, 1986), and interfere with the generation of motor activity in the spinal cord of the lamprey and Xenopus (Dale and Roberts, 1984; Brodin and Grillner, 1985). Calcium dependence of these processes, and the excitotoxic response to L-glutamate (Choi, 1985) suggests that the presence of long-duration NMDAreceptor-mediated EPSPs, or the activation of NMDA-receptors by exogenously applied amino acids, may trigger the elevation of cytoplasmic free calcium required for LTP, for the maintenance of pacemaker-like motor activity, and for excitotoxicity.

The direct demonstration of calcium influx gated by NMDA receptors, and a subsequent increase in cytoplasmic free calcium, would fulfill a general requirement of the processes described above. With this in mind, we have used arsenazo III to measure calcium transients evoked by excitatory amino acids applied to spinal cord neurons. To investigate agonist-gated calcium influx separately from that due to conventional voltagegated channels, we performed our experiments under voltage clamp. A short paper describing some of our results has been published (MacDermott et al., 1986). Our experiments show that in spinal neurons, elevation of cytoplasmic free calcium can occur via ion flux through either voltage-dependent calcium channels or excitatory amino acid-receptor channels of the NMDA subtype. Responses to kainate and quisqualate were usually associated with minimal calcium signals.

\section{Materials and Methods}

Spinal cords and dorsal root ganglia from $13 \mathrm{~d}$ mouse embryos' (C57BL/ $6 \mathrm{~J})$ were dissociated and plated on collagen-coated tissue culture dishes, as previously described (Mayer and Westbrook, 1984). After 1-3 weeks in culture, electrophysiological experiments were performed at room temperature $\left(\approx 25^{\circ} \mathrm{C}\right)$ on the stage of a Nikon diaphot inverted microscope. The recording solution contained (in $\mathrm{mm}$ ): $145 \mathrm{NaCl}, 2.5 \mathrm{KCl}$, $2.5 \mathrm{CaCl}_{2}, 10 \mathrm{HEPES}, 10$ glucose, with no added $\mathrm{Mg}$ salts; $\mathrm{pH}$ was adjusted to 7.3 using $\mathrm{NaOH}$, and osmolarity to 325 mosmol using sucrose. Spontaneous activity and synaptic transmission were reduced by adding $1 \mu \mathrm{M}$ tetrodotoxin. The presence of micromolar amounts of $\mathrm{Mg}^{2+}$, in such solutions is sufficient to confer voltage sensitivity on the response to NMDA, although, compared to responses recorded in the presence of millimolar amounts of $\mathrm{Mg}^{2+}$, the peak of the NMDA cur- rent-voltage relationship is shifted to more negative potentials (e.g., Westbrook and Mayer, 1986).

The intracellular solution for patch recording contained (in mu): 140 K-gluconate, $2 \mathrm{MgCl}_{2}, 0.57-1.07 \mathrm{Na}$-arsenazo III ( $98 \%$ pure; Sigma No. 8891 , lot $92 \mathrm{~F}-7386$ ), and 10 HEPES adjusted to $\mathrm{pH} 7.2$ with $\mathrm{KOH}$; sucrose was added to adjust the osmolarity to 310 mosmol. In the majority of the experiments, the patch solution contained $0.71 \mathrm{~mm}$ arsenazo III (calculated using the molecular weight of the free acid, with $11 \mathrm{~mol}$ of $\mathrm{H}_{2} \mathrm{O}$ and $5 \mathrm{~mol}$ of $\mathrm{Na}^{+}$per mole of arsenazo III). In some experiments $\mathrm{CsCl}$ or $\mathrm{CsMeSO}_{3}$ was substituted for $\mathrm{K}$-gluconate. $\mathrm{Ca}^{2}$ । was buffered using $1.1 \mathrm{~mm}$ EGTA, with or without $0.1 \mathrm{mM} \mathrm{CaCl}_{2}$; similar results were obtained in a few recordings using patch solutions containing $5 \mathrm{~mm}$ EGTA or solutions to which EGTA and $\mathrm{CaCl}_{2}$ were not added (in this solution, arsenazo III chelates the residual free calcium normally present in intracellular solutions). In some experiments (as detailed in the figure legends), $2 \mathrm{~mm}$ ATP, $20 \mathrm{~mm}$ creatine phosphate, and $25 \mathrm{U} / \mathrm{ml}$ of creatine phosphate kinase were added as an "ATP regenerating system" (Forscher and Oxford, 1985) to reduce calcium current rundown.

A calcium-sensitive electrode was used to measure free $\mathrm{Ca}^{2+}$ in some of the patch solutions described above. The K-gluconate-based solution with $1.1 \mathrm{mM}$ EGTA had a pCa of 8.2 , which decreased to 8.03 on adding arsenazo III; the same solutions, with the addition of $0.1 \mathrm{~mm}$ $\mathrm{CaCl}_{2}$, had pCa values of 7.66 and 7.5 , respectively.

Excitatory amino acids were dissolved in the recording solution and applied to the soma of spinal cord neurons by miniperfusion from patch pipettes positioned $20-40 \mu \mathrm{m}$ from the somatic membrane. Normally brief pulse applications were applied to evoke a large transient excitatory response, using $1 \mathrm{~mm}$ L-glutamate, $100-150 \mu \mathrm{M}$ kainate, $1 \mathrm{~mm}$ NMDA, 10-20 $\mu \mathrm{M}$ quisqualate, or $50 \mu \mathrm{M}$ GABA. In some experiments $50 \mu \mathrm{M}$ NMDA was applied for periods of $10-20 \mathrm{sec}$ to evoke a sustained inward current.

Optical techniques. The preparation was illuminated using a quartz halogen source powered by a stabilized DC supply unit and focused onto the cell body of spinal neurons $15-20 \mu \mathrm{m}$ in diameter. Light was collected using a $20 \times$ phase-contrast objective of numerical aperture 0.40 . Prior to the recording of optical responses, the phase ring in the condenser was removed from the light path. An iris diaphragm was used to restrict the microscopic field used for spectral analysis to a diameter of $50 \mu \mathrm{m}$, and light passing through this field was focused onto a diffraction grating. Photodiodes were used to measure the intensity of the light at $570,610,660$, and $700 \mathrm{~nm}$, and were initially positioned using narrow-band interference filters; each photodiode sampled a spectral bandwidth of approximately $30 \mathrm{~nm}$, centered at the desired frequency (for further details, see Smith, 1986). Records are calibrated as changes in transmittance from the prestimulus baseline, defined as $100 \%$. Calibration of responses in terms of changes in free calcium was not attempted because of difficulties in restricting the optical field only to light passing through the soma, and in estimating the pathlength.

Recording and analysis. Voltage clamp was performed using a discontinuous voltage-clamp amplifier (Axoclamp-2; Axon Instruments) operating at around $10 \mathrm{kHz}$, with patch pipettes of $\approx 5 \mathrm{M} \Omega$ resistance for whole-cell recording (e.g., Mayer, 1985; Westbrook et al., 1986). Membrane potential, clamp current, and optical transmittance were displayed on a 6-channel Gould Brush recorder, amplified, filtered, and digitized on-line using a PDP 11/73-based microcomputer system. When required, curve-fitting was performed using the Dataplot program (Filliben, 1984) running on a VAX $11 / 750$ computer. The records shown in the figures are photographic traces of either the raw chart records or digitized data.

Experiments were performed on a total of 54 spinal cord neurons in which calcium transients were measured using arsenazo III. In vitro the absorbance spectrum of arsenazo III shows characteristic wavelengthdependent changes on binding calcium, which also occur in the cytoplasm of spinal cord neurons, suggesting that there is a similar absorbance spectrum in situ over the range of wavelengths used for our experiments (see Fig. 1). Thus $\mathrm{Ca}^{2+}$ entry triggered by depolarizing voltage steps evoked no change in transmittance at $570 \mathrm{~nm}$, the isosbestic wavelength for the $\mathrm{Ca}^{2+}$-arsenazo III complex, while a spectrally dependent decrease in transmittance was recorded at 610,660 , and 700 $\mathrm{nm}$. To increase the signal-to-noise ratio in recording circumstances less favorable than those in Figure 1, we usually recorded optical traces as difference records of the wavelength pairs $570-660$ and $700-660 \mathrm{~nm}$, which gave an upwards deflection for an increase in $\left[\mathrm{Ca}^{2+}\right]_{\mathrm{i}}$. The change in transmittance recorded at $660 \mathrm{~nm}$ exceeded that at $610 \mathrm{~nm}$ (Fig. 1), 
A

570

610

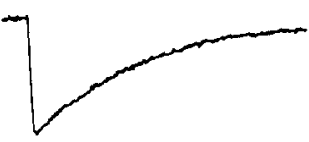

660

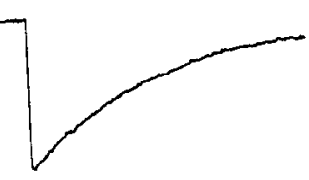

700

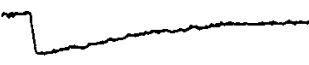

Figure 1. A, B, Wavelength-dependent changes in arsenazo III absorbance evoked by a depolarizing voltage step $500 \mathrm{msec}$ in duration, from -60 to 0 $\mathrm{mV}$, applied to a spinal cord neuron voltage-clamped using the whole-cell recording technique, and loaded with $0.71 \mathrm{~mm}$ arsenazo III. $A$, Traces were recorded simultaneously at wavelengths of $570,610,660$, and $700 \mathrm{~nm}$. The lower trace shows the membrane potential; note that the peak increase in absorbance occurs at $660 \mathrm{~nm}$, with no change at $570 \mathrm{~nm}$. $B$, Traces were recorded later in the experiment, and their smaller peak amplitude reflects calcium current rundown during whole-cell recording. The lower set of optical records was obtained by subtracting the wavelength pairs $610-660$ and $570-660$ $\mathrm{nm}$, producing upward deflections during elevation of $\left[\mathrm{Ca}^{2+}\right]_{\mathrm{i}}$. The lower half of the figure shows absorbance spectra obtained on adding calcium to a K-gluconate patch solution containing $0.7 \mathrm{~mm}$ arsenazo III and $2 \mathrm{~mm} \mathrm{MgCl}_{2}$; the spectra were recorded using a cuvette of 100 $\mu \mathrm{m}$ pathlength. The total amount (in $\mathrm{mm}$ ) of $\mathrm{CaCl}_{2}$ added to the patch solution is indicated beloweach trace. Note the calcium-dependent peaks at 610 and $660 \mathrm{~nm}$, and the isosbestic points at shorter wavelengths.
B

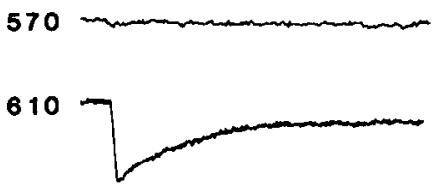

660
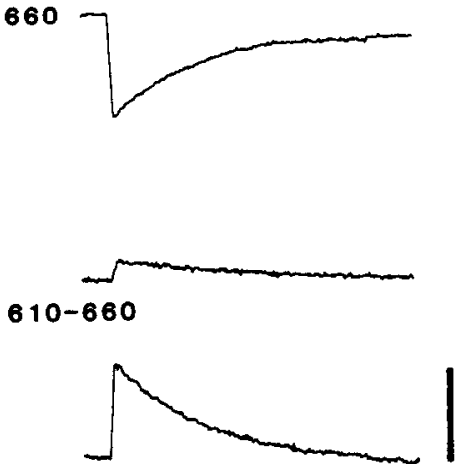

$0.2 \% T$ $570-660$

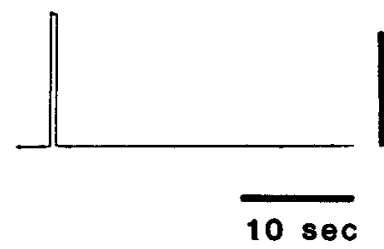

$50 \mathrm{mV}$

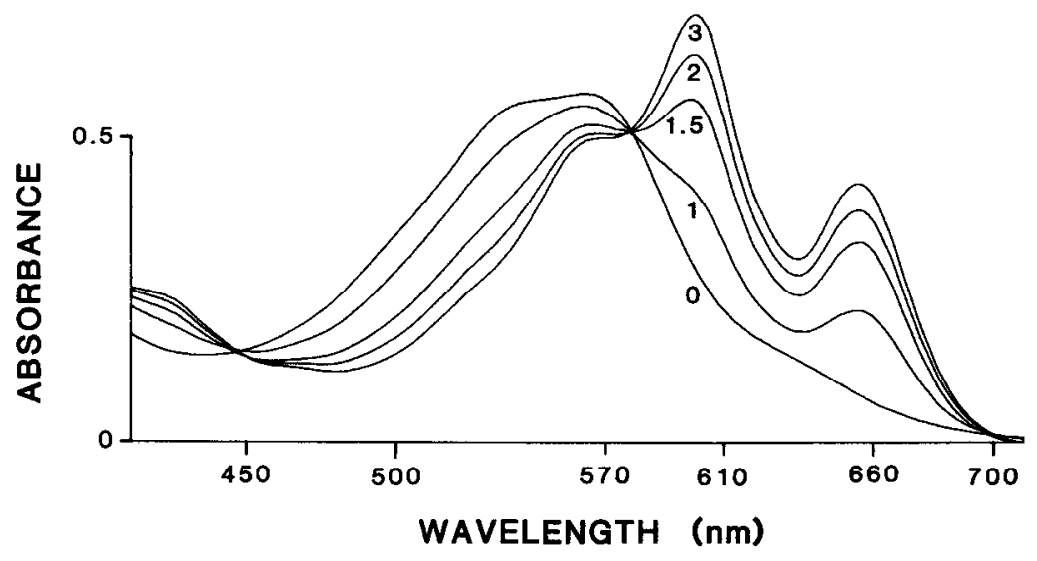

consistent with a change in free $\mathrm{Ca}^{2+}$, rather than with a change in $\mathrm{pH}$ or free $\mathrm{Mg}^{2+}$.

In all of our experiments, neurons were first clamped at -50 to -60 $\mathrm{mV}$, and depolarizing voltage steps $0.5-2.0 \mathrm{sec}$ in duration were used to check the adequacy of the optical recording system prior to any more detailed investigation of changes in $\left[\mathrm{Ca}^{2+}\right]_{\mathrm{i}}$. During this initial recording period, responses to drugs applied by miniperfusion were sometimes associated with large optical artifacts, which we believe were the result of leakage of arsenazo III from patch pipettes into the extracellular solution prior to sealing and to the subsequent movement of this extracellular pool of dye during microperfusion of agonists. If this occurred, useful information could still be recorded later in the experiment, after the dye had diluted sufficiently in the recording chamber.

\section{Results}

Calcium transients evoked following activation of voltagedependent Ca channels

Single-channel and whole-cell recording experiments have been used to examine the current-voltage relationship of calcium channels and calcium currents in some detail, and it is known that for many cells depolarization from $-60 \mathrm{mV}$ can open a channel with a threshold for activation of around $-30 \mathrm{mV}$ (i.e., the L-type channel; Nowycky et al., 1985), which generates peak inward current at approximately $+10 \mathrm{mV}$, and which with fur- 


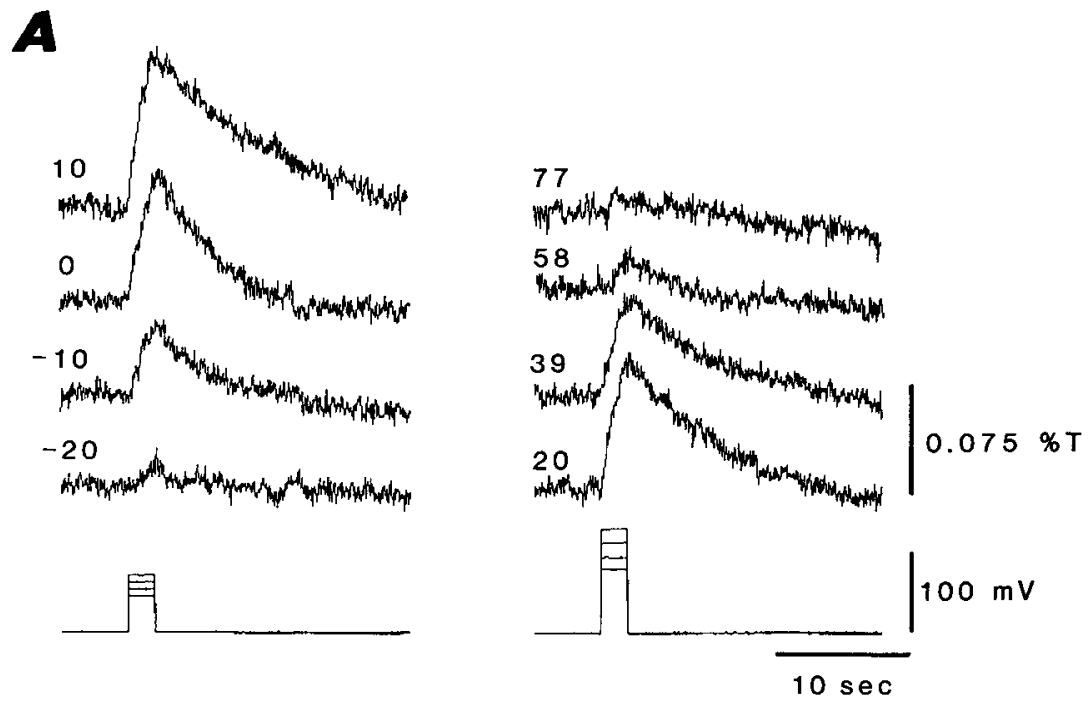

$\boldsymbol{B}$

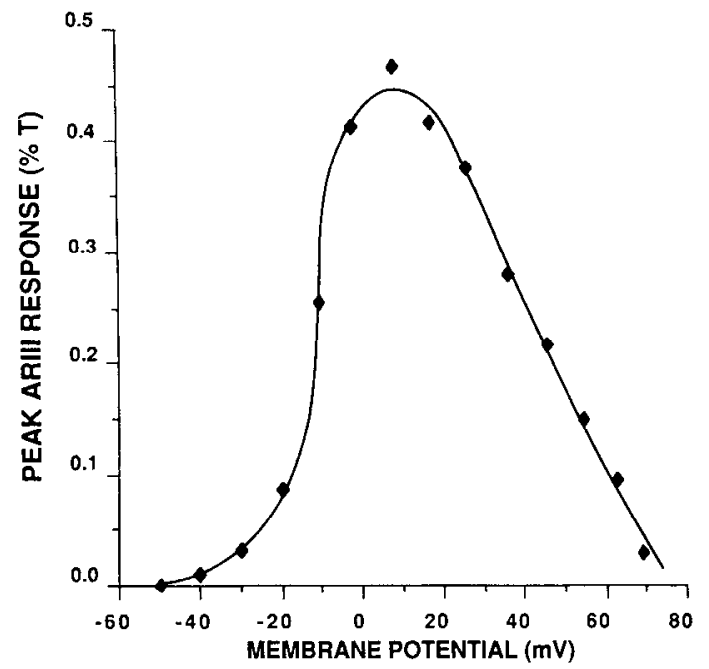

Figure 2. A, Absorbance traces (570$660 \mathrm{~nm}$ ) during a series of progressively larger depolarizing voltage steps $2 \mathrm{sec}$ in duration, applied from a holding potential of $-60 \mathrm{mV}$. The signals increase in amplitude with depolarization over the range -30 to $+10 \mathrm{mV}$, and decrease in amplitude with further depolarization over the range +20 to $+77 \mathrm{mV}$. $B$, Graph of data obtained from another spinal cord neuron using a similar protocol of voltage steps; in this experiment, the optical responses were unusually large, and threshold responses were detectable at -40 and $-30 \mathrm{mV}$. The shape of the absorbance-voltage plot is similar to that expected for $\mathrm{Ca}^{2+}$ influx through voltage-dependent $\mathrm{Ca}^{2+}$ channels. ther depolarization shows a reduction in inward current amplitude, reflecting a decrease in driving force for $\mathrm{Ca}^{2+}$ influx. The elevation of $\left[\mathrm{Ca}^{2+}\right]_{i}$ recorded in spinal cord neurons $(n=$ 6) using arsenazo III during a series of depolarizing voltage steps paralleled the current-voltage relationship for calcium current, such that the peak calcium transient occurred close to $+10 \mathrm{mV}$ and declined with further depolarization (Fig. 2). The shape of such transmittance-voltage relationships, along with the spectra shown in Figure 1, strongly suggests that the optical changes we recorded reflect transient changes in $\left[\mathrm{Ca}^{2+}\right]_{\mathrm{i}}$.

For depolarizing steps lasting up to several hundred milliseconds, the peak change in transmittance increased linearly with step duration (Fig. 3). Assuming that calcium influx occurs at a constant rate during such voltage steps, then the present experiments provide an estimate of relative changes in $\left[\mathrm{Ca}^{2+}\right]_{i}$ over at least one order of magnitude, as judged by the peak amplitude of the transmittance signal. Responses to both voltage steps and application of excitatory amino acids were normally studied using such brief stimuli. For longer step durations the arsenazo III response approached an asymptote, apparently following single-exponential kinetics (Fig. 4). The asymptotic rise in $\left[\mathrm{Ca}^{2+}\right]_{i}$ shown in Figure 4 might reflect progressive inactivation of inward $\mathrm{Ca}^{2+}$ current (e.g., Bolsover, 1986); however, strikingly similar asymptotic arsenazo III responses have been recorded in molluscan neurons during intracellular injection of $\mathrm{Ca}^{2+}$ via microelectrodes (Gorman and Thomas, 1980b), suggesting local saturation of the indicator dye during large and rapid $\mathrm{Ca}^{2+}$ fluxes.

Decay of arsenazo III responses following voltage steps showed complex, multiexponential kinetics, such that recovery to baseline transmittance values always took much longer than did the rising phase of the response (e.g., Figs. 2-4, 12); nearly identical results have been obtained in studies on molluscan neurons (e.g., Gorman and Thomas, 1980a; Smith and Zucker, 1980). The rate of recovery of $\left[\mathrm{Ca}^{2+}\right]_{i}$ to baseline values varied with the duration of whole-cell recording (see Figs. 12 and 13). For the long-duration response shown in Figure 4 the rising phase occurred with a time constant of $7.2 \mathrm{sec}$; recovery followed 2 exponentials of time constants 19.3 and $81 \mathrm{sec}$, respectively, with the faster process dominating the response (ratio of fast to slow intercepts at time $0=3.34$ ). For responses evoked by briefer voltage steps soon after the start of whole-cell recording, a faster recovery process of time constant 1-4 sec was also observed in addition to one of time constant 10-20 sec, and for these briefer stimuli a contribution of the slowest process was not detectable (see Fig. 12). 

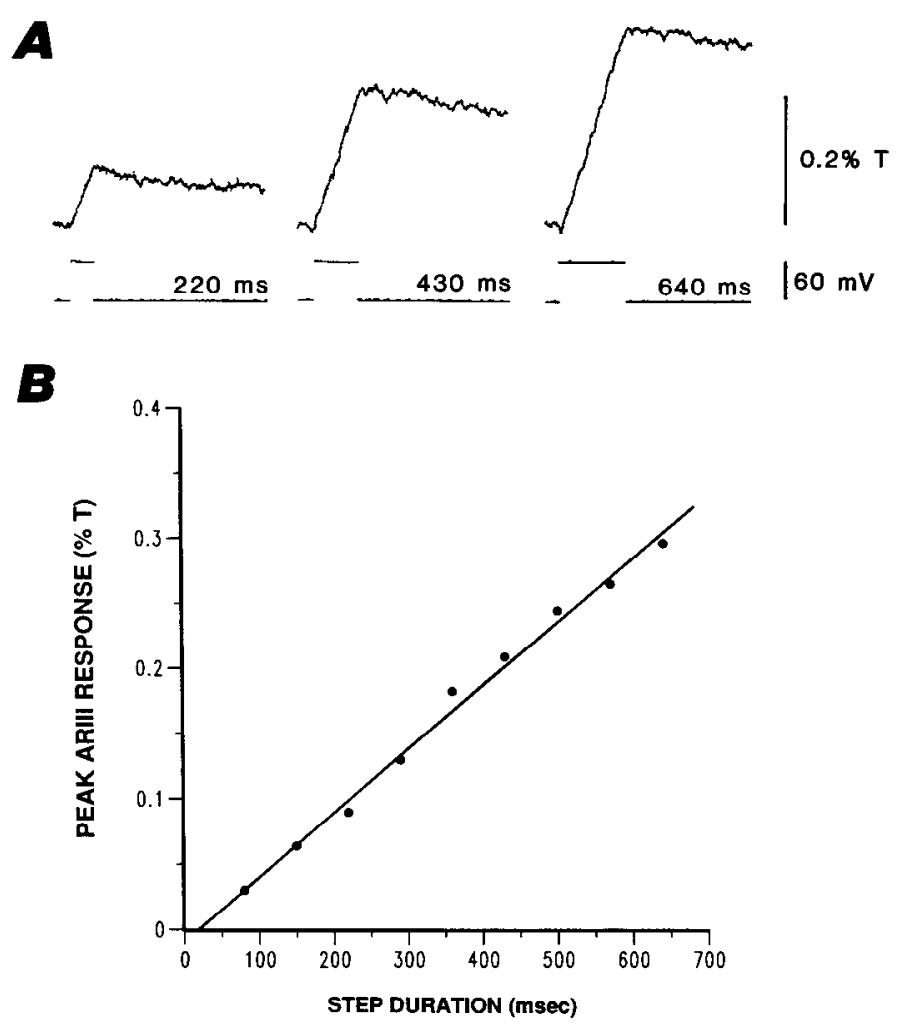

Figure 3. $\left[\mathrm{Ca}^{2+}\right]_{\mathrm{i}}$ rises at a linear rate during brief depolarizing voltage steps. $A$, Examples of absorbance traces (570-660 nin) recorded during voltage steps from -60 to $0 \mathrm{mV}$ and lasting 220-640 msec. Sufficient time was allowed between steps for the absorbance trace to decay to baseline values. $B$, Plot of the peak absorbance response as a function of step duration for individual responses $80-640 \mathrm{msec}$ in duration. The line was fitted by linear regression $(r=0.99)$ and intercepts the time axis at $12.3 \mathrm{msec}$, the lower limit of sensitivity for single responses in this neuron. The results suggests that over the range explored in this experiment, $\left[\mathrm{Ca}^{2+}\right]_{i}$ rises continuously with time during activation of $\mathrm{Ca}^{2+}$ channels.

\section{Calcium transients evoked by excitatory amino acids}

Spinal cord neurons respond to excitatory amino acids with a brisk depolarizing response, which alone is sufficient to evoke calcium entry through voltage-dependent calcium channels. Thus depolarizations evoked by kainate and NMDA resulted in transient increases in cytoplasmic free calcium (Fig. 5A). However, when voltage clamp was applied to prevent the depolarizing response, inward current responses to NDMA were still accompanied by a transient increase in cytoplasmic free calcium (Fig. $5 B$ ), whereas the inward current evoked by kainate was accompanied by only a small calcium transient.

To examine the receptor specificity of the amino acid-evoked increase in cytoplasmic free calcium we recorded under voltage clamp the arsenazo III response to applications of NMDA and either kainate or quisqualate, using agonist-evoked currents of similar amplitude. In individual neurons, responses to NMDA were always accompanied by much larger optical signals than those evoked by either kainate or quisqualate (Fig. $6, A, B$ ). This paired application of excitatory amino acids to single cells was chosen to minimize the influence of variations in the calcium transient response resulting from differences in sensitivity of the arsenazo III response that occurred from cell to cell and with time during individual experiments (e.g., Figs. 12, 13). Responses to L-glutamate, a mixed agonist with activity at both
NMDA and either kainate or quisqualate receptors (Watkins and Evans, 1981; Mayer and Westbrook, 1984; Westbrook and Mayer, 1984), were also accompanied by calcium transients similar in amplitude to those evoked by NMDA (Fig. 6C).

Spinal neurons loaded with chloride generated large inward currents in response to the inhibitory transmitter GABA, but these were not accompanied by any detectable elevation of cytoplasmic free calcium (Fig. $6 \mathrm{D}$ ). This provides a useful control experiment for the effect of inward current, and in particular argucs against the possibility that an inadequatc space clamp allows calcium entry through conventional depolarization-activated calcium channels in the dendritic membrane. Further support for this was obtained by moving the field used for measurement of the arsenazo III response away from the soma, its normal position, and onto the dendritic arborization. This caused a loss of the arsenazo III response, which was restored on returning the optical field to the soma, suggesting that calcium entry in dendrites did not contribute to the signals evoked by focal application of excitatory amino acids to the soma of spinal cord neurons under voltage clamp.

The calcium transient evoked by both NMDA and kainate showed a clear dose dependence, and experiments on individual neurons showed a much steeper slope of the dose-response relationship for responses to NMDA than to kainate (Fig. 7A). In these experiments the amplitude of the calcium response evoked by NMDA varicd by a factor of 2 for similar-sized current responses recorded in different neurons, although when responses from all neurons were pooled (Fig. $7 B$ ), the difference in slope for responses evoked by NMDA and kainate was still statistically significant $(p \leq 0.001)$. One explanation for this result would be that there is a measurable calcium influx through both NMDA- and kainate-receptor channels, with NMDA-receptor channels being more calcium-permeable; a similar relationship could also result if kainic acid had a weak agonist action at calcium-permeable NMDA-receptor channels (e.g., Cull-Candy and Usowicz, 1987; Jahr and Stevens, 1987), in addition to its main site of action at kainate receptors coupled to ion channels with a very low calcium permeability (Mayer and Westbrook, 1985b, 1987b). Our results argue against the possibility that a rise in $\left[\mathrm{Na}^{+}\right]_{i}$ following $\mathrm{Na}^{+}$influx through amino acid-activated ion channels triggers $\mathrm{Na}^{+}-\mathrm{Ca}^{2+}$ exchange or $\mathrm{Ca}^{2+}$ release from mitochondria (Schoffelmeer and Mulder, 1983), since if this were to contribute significantly to the $\left[\mathrm{Ca}^{2+}\right]_{i}$ transients recorded in our experiments, then kainate, quisqualate, and NMDA should all evoke similar responses.

\section{Calcium flux through NMDA-receptor channels}

Several excitatory amino acids bind to NMDA receptors with a micromolar affinity constant, as determined using displacement of ${ }^{3} \mathrm{H}-\mathrm{AP} 5$ from rat brain membrane preparations (Lglutamate, $0.9 \mu \mathrm{M}$, I-homocysteate, $3.9 \mu \mathrm{M}$, L-aspartate, $11 \mu \mathrm{M}$, NMDA, $11 \mu \mathrm{M}$; Olverman et al., 1984). In most of our experiments, agonists were applied at high concentrations, in brief puffs, to evoke large, transient responses. However, a $50 \mu \mathrm{M}$ concentration of NMDA, applied for longer periods, evoked a sustained inward current accompanied by both an increase in membrane current variance, reflecting the open-shut transitions of ion-channel gating (Nowak et al., 1984), and a large optical response, reflecting an increase in cytoplasmic calcium (Fig. 8A).

NMDA-receptor channels also show ion-channel block by physiological concentrations of $\mathrm{Mg}^{2+}$; this block reduces current flow through the channel, producing a voltage-dependent re- 
A

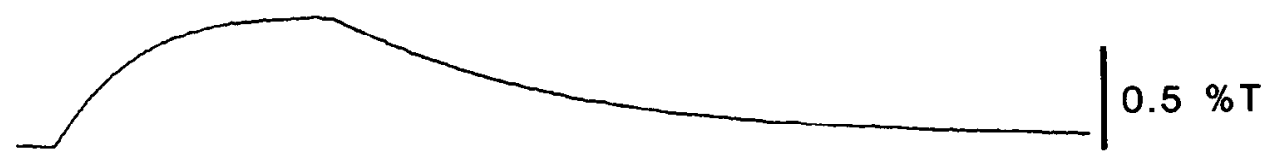

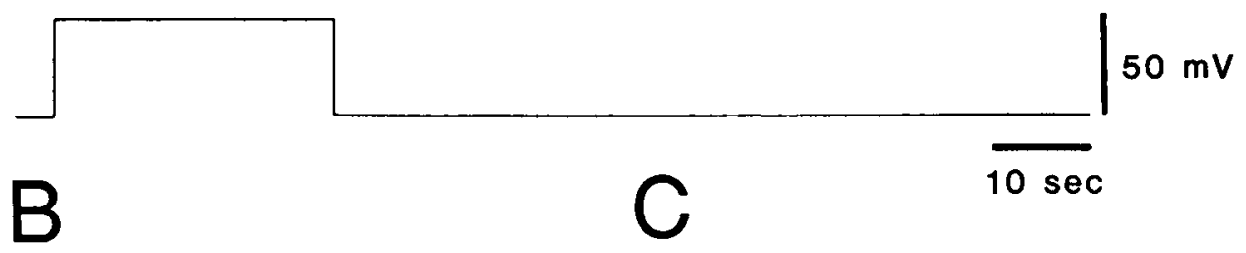

ARIII RESPONSE VERSUS STEP DURATION

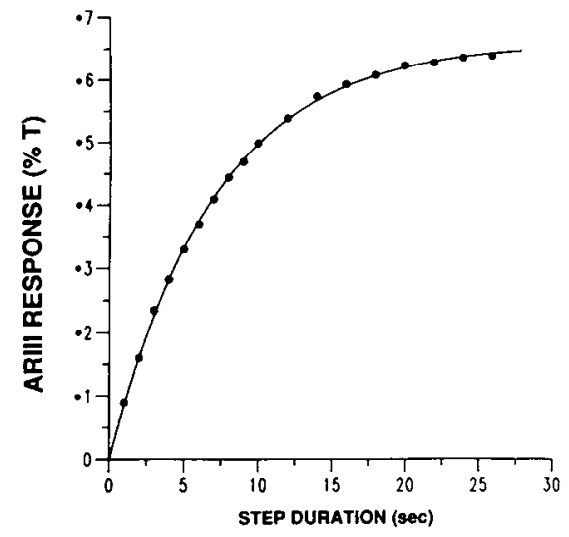

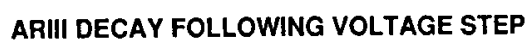

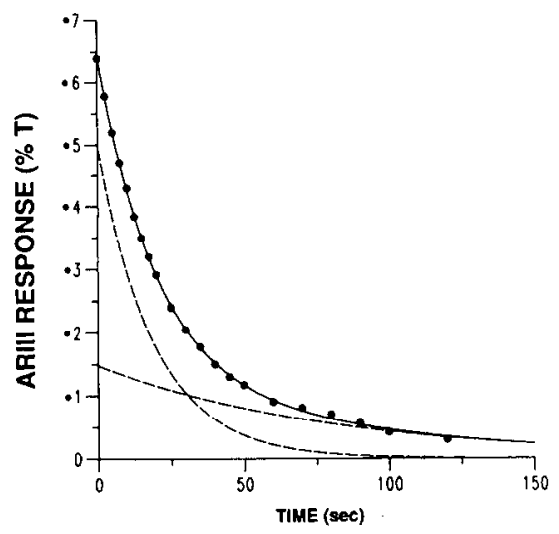

Figure 4. A, Arsenazo III response recorded during a voltage step from -60 to $-10 \mathrm{mV}$, and lasting $28.5 \mathrm{sec}$. The rise in absorbance is asymptotic, and, as shown in $B$, can be fitted by a single exponential of time constant $7.2 \mathrm{sec} . C$, Decay of the arsenazo III response following this voltage step occurs slowly, and can be described by the sum of 2 exponentials of time constants 19.3 and $81.2 \mathrm{sec}$, with an amplitude ratio (fast : slow, measured at the start of the decay process) of 3.27 . This response was recorded following several depolarizing stimuli $64 \mathrm{~min}$ after the start of whole-cell recording, at which time it is likely that a faster $\mathrm{Ca}^{2+}$ sequestration process of time constant 1-4 sec would be inoperative (see Figs. 12, 13). The patch solution contained the ATP. regenerating system described in Materials and Methods. sponse (Mayer et al., 1984; Nowak et al., 1984; Mayer and Westbrook, 1985a). High concentrations of $\mathrm{Mg}^{2+}$ have been shown to interfere with the influx of calcium through NMDAreceptor channels (see MacDermott et al., 1986, and Fig. 9). However, in the presence of $0.8 \mathrm{mM} \mathrm{Mg}^{2+}$, when the membrane potential was held at $-35 \mathrm{mV}$ to partially relieve the blocking action of $\mathrm{Mg}^{2+}$, we have becn ablc to measurc inward current responses to NMDA accompanied by increases in cytoplasmic free calcium (Fig. $8 B$ ). More quantitative measurements of the calcium flux through NMDA-receptor channels in the presence of physiological concentrations of $\mathrm{Mg}^{2+}$ should be feasible using more sensitive dyes, such as fura- 2 .

L-Glutamate is a mixed agonist with activity at both NMDA and non-NMDA receptors (Watkins and Evans, 1981; Mayer and Westbrook, 1984; Westbrook and Mayer, 1984), and is likely to be the major endogenous agonist acting at NMDA receptors. Block by $\mathrm{Mg}^{2+}$ of calcium transients evoked by L-glutamate (as shown in Fig. 9) reflects the agonist action of L-glutamate at NMDA receptors. NMDA-evoked arsenazo III responses showed a $\mathrm{Mg}^{2+}$ sensitivity similar to that of $\mathrm{L}$-glutamate (e.g., MacDermott et al., 1986). This suggests that the arsenazo III responses evoked by excitatory amino acids reflect $\mathrm{Ca}^{2+}$ flux through NMDA-receptor ion channels, rather than activation of receptor-coupled second messenger production and the release of $\mathrm{Ca}^{2+}$ from intracellular stores. On the other hand, excitatory amino acids, which stimulate inositol phospholipid metabolism, appear to act at quisqualate receptors (Sladeczek et al., 1985; Nicoletti et al., 1986), in contrast to the response we describe here, which is clearly linked to activation of NMDA receptors.

To examine the voltage dependence of calcium transients evoked by activation of NMDA receptors, responses to a constant pulse application of NMDA were recorded over the membrane potential range -100 to $+60 \mathrm{mV}$. The amplitude of calcium transients evoked by NMDA varied with the driving force for inward current over the membrane potential range 0 to -60 $\mathrm{mV}$, and declined during further hyperpolarization, as shown in Figurc 10, reflecting a fall in conductance due to channel block by micromolar amounts of $\mathrm{Mg}^{2+}$. Of interest are the responses recorded at $0 \mathrm{mV}$, the NMDA reversal potential, which show a small increase in cytoplasmic free calcium with no net current flow, or even at small positive membrane potentials at which outward current flow through NMDA-receptor channels is still accompanied by small $\left[\mathrm{Ca}^{2+}\right]_{\mathrm{i}}$ transients. We interpret this as reflecting a balance in charge transfer through the ion channel, such that influx of $\mathrm{Na}^{+}$and $\mathrm{Ca}^{2+}$ is balanced by efflux of $\mathrm{K}^{+}$; at extremely positive membrane potentials, the outward current evoked by NMDA is not accompanied by a calcium transient. These results further support our suggestion that the calcium transient evoked by NMDA-receptor activation results from $\mathrm{Ca}^{2+}$ flux through the ion channels opened by NMDA, rather than from the production of some second messenger which releases $\mathrm{Ca}^{2+}$ from intracellular stores. This distinction is mechanistically important in the light of experiments describing stimulation of the production of inositol phosphates by excitatory amino acids (Sladeczek et al., 1985; Nicoletti et al., 1986), since inositol trisphosphate $\left(\mathrm{IP}_{3}\right)$ is a second messenger with calciummobilizing properties (Berridge and Irvine, 1984).

The ability of arsenazo III to signal transient elevations in cytoplasmic free calcium can be used to examine the influence of $\left[\mathrm{Ca}^{2+}\right]_{\mathrm{i}}$ on responses to excitatory amino acids. We previously reported that responses to a large dose of NMDA were followed 


\section{CURRENT CLAMP}

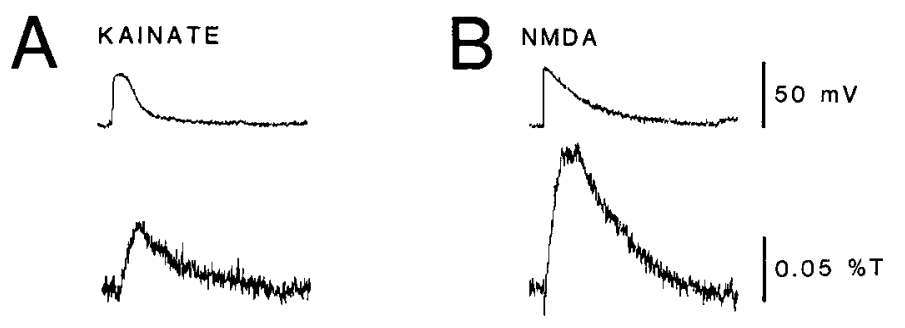

VOLTAGE CLAMP
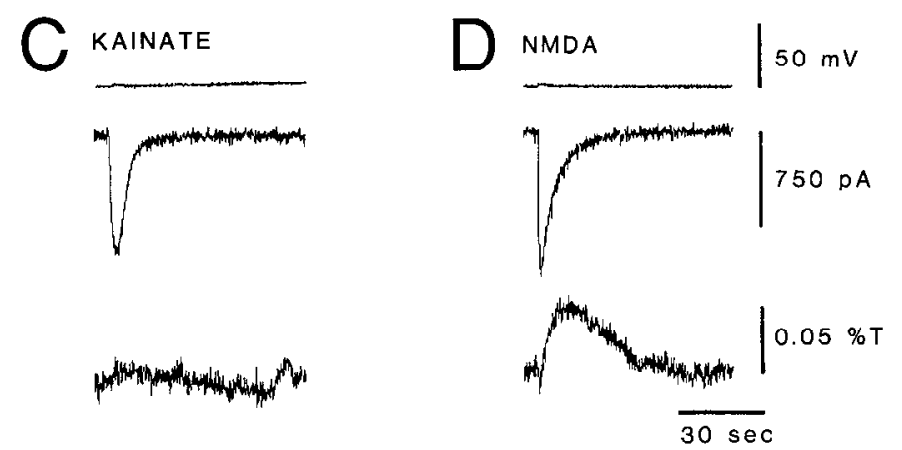

Figure 5. $\mathrm{Ca}^{2+}$ signals during excitatory amino acid-evoked depolarization reflects activation of both voltage-dependent $\mathrm{Ca}^{2+}$ channels and an agonist-gated rise in $\left[\mathrm{Ca}^{2+}\right]_{\mathrm{i}} . A$ and $B$, Depolarizing responses of one spinal cord neuron under current clamp to application of kainic acid $(30 \mathrm{msec}, 150 \mu \mathrm{M})$ and $N$-methyl-D-aspartic acid $(250 \mathrm{msec}, 1 \mathrm{~mm})$. Both responses are accompanied by a rise in $\left[\mathrm{Ca}^{2+}\right]_{\mathrm{i}} . C$ and $D$, Responses recorded from this same neuron to identical agonist applications, but voltage-clamped at its resting potential. The inward current response to kainic acid $(C)$ is accompanied by only a small rise in $\left[\mathrm{Ca}^{2+}\right]_{i}$, in contrast to the large transient accompanying the inward current evoked by NMDA $(D)$.

by desensitization, as were NMDA responses following depolarizing voltage jumps (Mayer and Westbrook, 1985a), and suggested that an elevation of $\left[\mathrm{Ca}^{2+}\right]_{\mathrm{i}}$ might underlie this response. The records shown in Figure 11 provide further support for this and show a reversible reduction of the response to NMDA evoked by a voltage step sufficient to elevate $\left[\mathrm{Ca}^{2+}\right]_{i}$. Further analysis of such responses will be required to determine whether $\mathrm{Ca}^{2+}$ has a direct action on NMDA-receptor channels, or whether the effect is secondary to elevation of $\left[\mathrm{Ca}^{2+}\right]_{i}$. The role of $\mathrm{Ca}^{2+}$ in the desensitization of agonist-activated receptor channels is currently not well defined, but has precedents, and similar results have been obtained in studies on nicotinic acetylcholine receptors (Scubon-Mulieri and Parsons, 1977; Miledi, 1980).

\section{Effect of $\mathrm{Ca}^{2+}$ clearance on responses to $\mathrm{NMDA}$}

In contrast to the rundown of voltage-dependent calcium current responses, the calcium transient evoked by a constant inward current response to NMDA progressively increased in size during periods of whole-cell recording lasting 1-2 hr. Initially, inward current responses to NMDA were accompanied by barely detectable increases in $\left[\mathrm{Ca}^{2+}\right]_{\mathrm{i}}$, at a time when depolarizing voltage steps evoked large, brisk calcium transients. Subsequently, while the calcium transient evoked by NMDA increased in amplitude, the calcium transient evoked by depolarizing voltage steps declined. During this period, $\left[\mathrm{Ca}^{2+}\right]_{\mathrm{i}}$ transients accompanying inward current responses to kainic and quisqualic acids

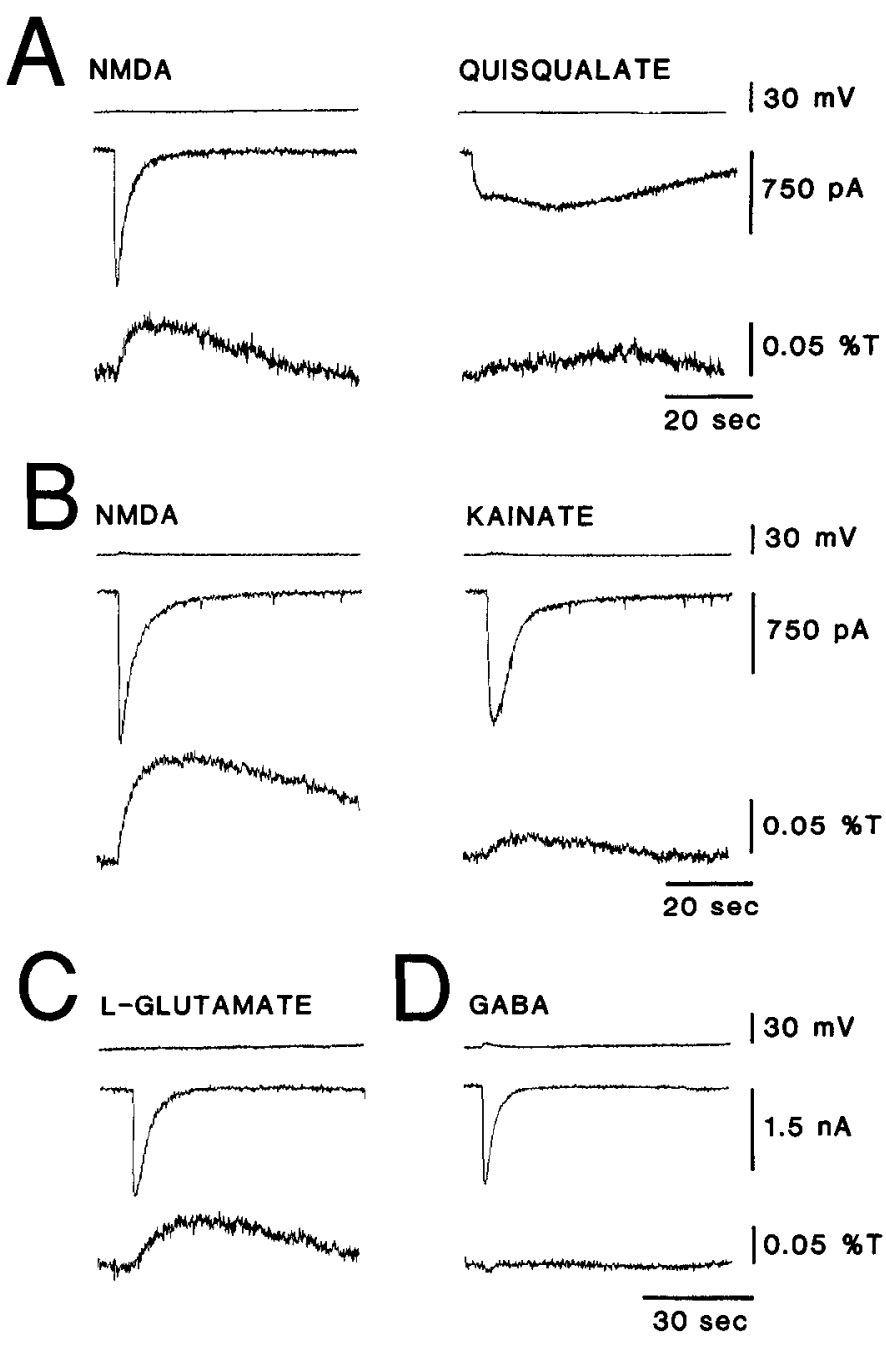

Figure 6. Agonist specificity of amino acid-evoked $\left[\mathrm{Ca}^{2+}\right]_{\mathrm{i}}$ transients. $A$ and $B$, Traces show paired responses recorded from single neurons. $C$ and $D$, Traces were recorded from individual neurons. All responses were recorded under voltage clamp and show inward currents evoked by amino acids and their accompanying absorbance traces (570-660 nm). $A$, A fast-rising $\left[\mathrm{Ca}^{2+}\right]_{\mathrm{i}}$ transient evoked by NMDA (20 msec, 1 $\mathrm{mm}$ ) and a much smaller response to quisqualic acid (15 msec, $100 \mu \mathrm{M})$ despite the much larger integral value of the quisqualate-evoked current. The response to quisqualate was evoked by a pulse application similar in duration to that used to apply NMDA, and the prolonged time course of the inward current, which is typical of quisqualate, reflects the occurrence of a postapplication hump similar to that accompanying desensitizing responses to high doses of cholinergic agonists (Adams, 1975). $B$, Responses to NMDA (60 msec, $1 \mathrm{~mm}$ ) and kainic acid (40 msec, $100 \mu \mathrm{M})$. Both are accompanied by fast-rising $\left[\mathrm{Ca}^{2+}\right]_{\mathrm{i}}$ transients, although the response to NMDA is much larger than that to kainic acid. $C$, Response to L-glutamic acid $(20 \mathrm{msec}, 1 \mathrm{~mm})$ accompanied by a $\left[\mathrm{Ca}^{2+}\right]_{\mathrm{i}}$ transient response comparable to that evoked by NMDA. $D$, Inward current response evoked by GABA $(80 \mathrm{msec}, 50 \mu \mathrm{M})$ applied to a chloride-loaded spinal cord neuron, accompanied by no change in $\left[\mathrm{Ca}^{2+}\right]_{\mathrm{i}}$

showed a similar increase in amplitude. The end of a useful recording period was usually signaled by a complete loss of response to voltage steps, coupled with a prolonged optical response to NMDA that showed little or no recovery to baseline. Our observations suggest that a reduction in the neuron's continued ability to regulate $\left[\mathrm{Ca}^{1+}\right]_{i}$ might explain these phenomena.

For example, we noted that the enhancement of $\left[\mathrm{Ca}^{2+}\right]_{\mathrm{i}}$ tran- 
A

PEAK AR III RESPONSE VERSUS dOSE

snous cau

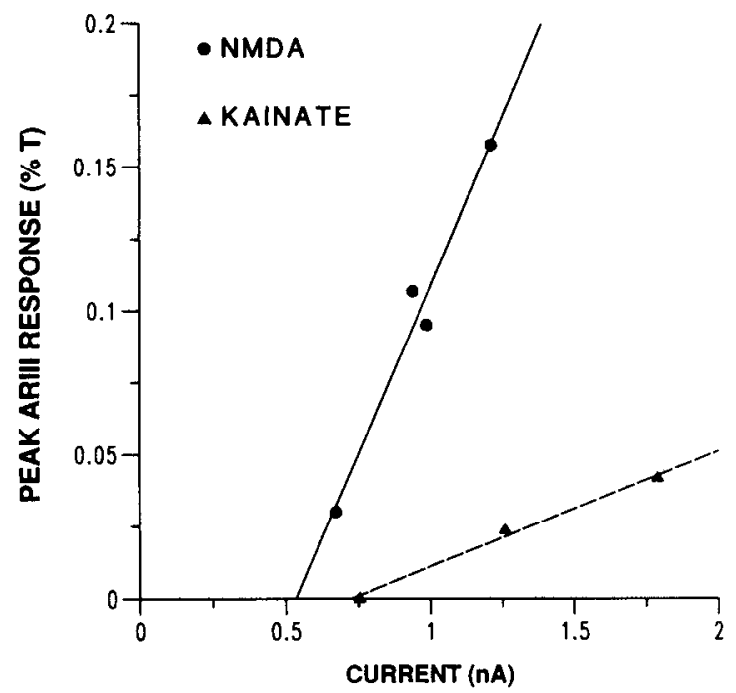

B
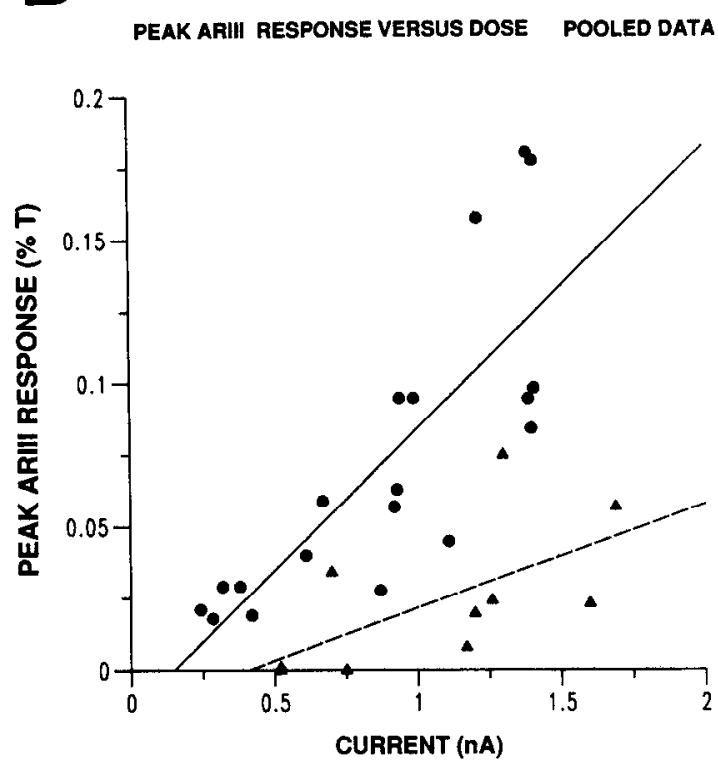

Figure 7. Dose dependence of arsenazo III responses evoked by NMDA and kainic acid. $A$, Responses of a single spinal cord neuron evoked by 3 doses of NDMA (0) and kainic acid ( $(\Delta)$, matched for peak inward current amplitude, and plotted as peak arsenazo III response (570-660 nM) versus peak inward current. Lines were fitted by linear regression. NMDA was applied using pressure pulses of 100 , 200, and 300 msec (1 mM NMDA); kainic acid was applied using pressure pulses of 5,10 , and $20 \mathrm{msec}(150 \mu \mathrm{M}$ kainate). $B$, Similar data obtained from 19 neurons. Although the values are scattered, regression lines again reveal a steeper slope for responses evoked by NMDA (๑), suggesting a greater rise in $\left[\mathrm{Ca}^{2+}\right]_{i}$ during activation of NMDA than during that of kainic acid receptors.

sients evoked by NMDA could be accelerated by evoking $\mathrm{Ca}^{2+}$ influx through voltage-dependent calcium channels (usually accomplished by holding the membrane potential at a depolarized value for several seconds), which suggests that the loading of cellular $\mathrm{Ca}^{2+}$ buffers was responsible for the increase in amplitude of the NMDA-evoked arsenazo III response. To test this we examined the rate at which $\mathrm{Ca}^{2+}$ transients evoked by brief voltage steps recovered to baseline values during a prolonged period of recording in which the membrane potential was first clamped at $-60 \mathrm{mV}$, then gradually depolarized to evoke additional $\mathrm{Ca}^{2+}$ influx, and subsequently returned to $-60 \mathrm{mV}$. For this experiment, $\mathrm{Mg}$-ATP was added to the intracellular solution to reduce $\mathrm{Ca}^{2+}$-channel rundown. The aim of this experiment was to determine whether the decay of calcium transients evoked by brief depolarizing voltage steps slowed during whole-cell recording, and, if so, to correlate this with changes in the amplitude of arsenazo III responses to a fixed dose of NMDA.

During the first $25 \mathrm{~min}$ of recording, both the peak calcium signal following a voltage step to $0 \mathrm{mV}$ and the subsequent rate of recovery of $\left[\mathrm{Ca}^{2+}\right]_{i}$ to baseline remained constant. During this same period the peak calcium signal evoked by NMDA also remained at a small constant value. The membrane potential was then progressively depolarized over the next $25 \mathrm{~min}$, and the recovery time constant of the calcium signal response to a voltage step became increasingly dominated by a slower process. Associated with this slow recovery was a large increase in the peak calcium response to NMDA. All of these changes remained constant over the final $20 \mathrm{~min}$, when the membrane potential was again held at $-60 \mathrm{mV}$. This experiment resulted in a striking correlation between the amplitude of the calcium transient response to NMDA and a switch from a fast to slow mechanism of the process regulating recovery of $\left[\mathrm{Ca}^{2+}\right]_{\mathrm{i}}$ to base- line values following depolarizing voltage steps (Figs. 12, 13). We assume that the decay of arsenazo III responses recorded during this experiment reflects the activity of cellular mechanisms responsible for clearance of calcium from the cytoplasm, e.g., buffering by $\mathrm{Ca}^{2+}$-binding proteins and uptake by cellular organelles (Baker and Schlaepfer, 1978), extrusion by $\mathrm{Na}^{+}-\mathrm{Ca}^{2+}$ exchange (Blaustein, 1974), and diffusion of $\mathrm{Ca}^{2+}$ to the interior of the cell (e.g., Smith, 1980).

On the basis of the above results we suggest that a plausible explanation for this switch would be saturation of $\mathrm{Ca}^{2+}$ storage sites associated with the fast clearance mechanism, such that $\mathrm{Ca}^{2+}$ sequestration becomes dependent on a slower mechanism, of lower affinity and higher capacity. We suggest that during the initial period of recording, the resting $\left[\mathrm{Ca}^{2+}\right]_{i}$ level is sufficiently low that during NMDA-receptor activation the fast clearance mechanism prevents a rise in $\left[\mathrm{Ca}^{2+}\right]_{i}$ throughout the cytoplasm, resulting in a small arsenazo III response. Later in the recording period, when $\mathrm{Ca}^{2+}$ is cleared more slowly, a larger volume of the cytoplasmic space senses the NMDA-evoked rise in $\left[\mathrm{Ca}^{2+}\right]_{\mathrm{i}}$, producing an arsenazo III response that is much larger and prolonged. We do not suggest that $\mathrm{Ca}^{2+}$ flux through NMDA receptors varies with time during whole-cell recording (for example, $\mathrm{Ca}^{2+}$ dependence of the reversal potential of responses to NMDA does not vary with time), or that the responses we describe differ from those occurring in intact cells.

\section{Discussion}

\section{$\left[\mathrm{Ca}^{2+}\right]_{i}$ transients measured using whole-cell recording}

The whole-cell recording technique greatly facilitates the introduction of experimental probes into the cytoplasmic space, and is an ideal approach for loading small mammalian neurons with water-soluble calcium indicators during electrophysiological recording. A similar approach to that used in the present exper- 
A NMDA 50 uM NO ADDED Mg
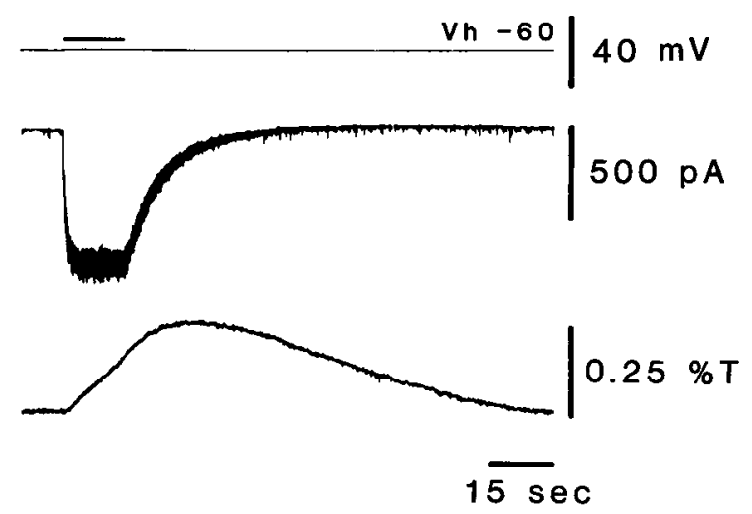

B
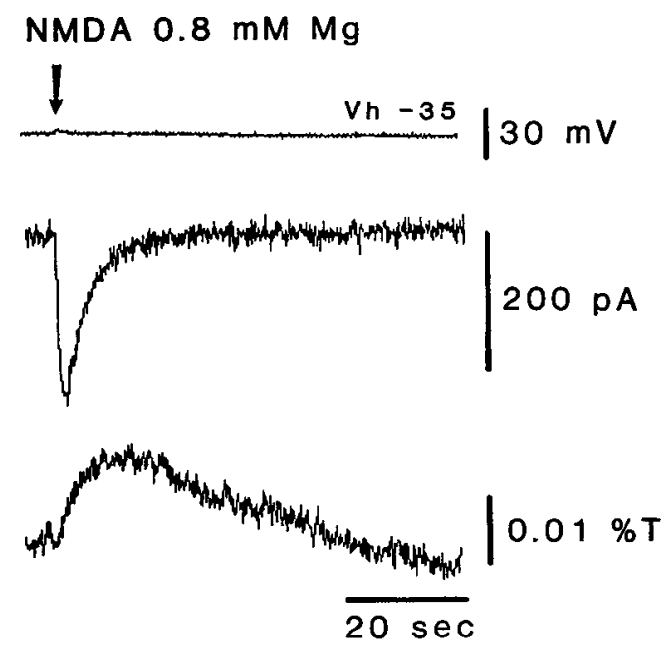

Figure 8. A, A large $\left[\mathrm{Ca}^{2+}\right]_{\mathrm{i}}$ transient response evoked by application of $50 \mu \mathrm{M}$ NMDA, suggesting that the response to NMDA reflects activation of receptors similar to those characterized in binding studies (Kd $\approx 10 \mu \mathrm{M}$; Olverman et al., 1984). $B$, Response to a brief $(300 \mathrm{msec})$ application of $1 \mathrm{~mm} \mathrm{NMD \Lambda}$ recorded with $0.8 \mathrm{~mm}$ external $\mathrm{Mg}^{2+}$, demonstrating that $\mathrm{Ca}^{2+}$ influx through NMDA-receptor channels can occur in the presence of physiological concentrations of $\mathrm{Mg}^{2+}$, despite a strong voltage-dependent blocking action on current flow through NMDA-receptor channels. iments was adopted by Almers and Neher (1985) to study the calcium dependence of exocytotic release from mast cells, using fura-2 as a $\mathrm{Ca}^{2+}$ indicator. Their finding that membrane-soluble $\mathrm{Ca}^{2+}$ indicators can partition into subcellular organelles increases the attractiveness of the whole-cell approach for measurement of cytoplasmic free $\mathrm{Ca}^{2+}$, since the dye solution in the pipette has direct access to the cell interior, allowing the use of charged, membrane-impermeant $\mathrm{Ca}^{2+}$ indicators. Despite this, the technique has some drawbacks, namely the lability of some conductance mechanisms and the disruption of metabolic processes during intracellular dialysis. For example, rundown of calcium currents (Kostyuk et al. 1981; Fenwick et al., 1982) and possible damage to $\mathrm{Ca}^{2+}$ homeostatic mechanisms is particularly worrying.

One aspect of the cell's normal physiology that whole-cell recording might reasonably be expected to alter is the rate of return to resting levels of free $\mathrm{Ca}^{2+}$ following a transient $\mathrm{Ca}^{2+}$ influx. Although details of the intracellular buffering mechanisms for $\mathrm{Ca}^{2+}$ are not known with any certainty, disruption of cellular ultrastructure during whole-cell recording (for example, swelling of endoplasmic reticulum), however limited (e.g., Neale et al., 1986), might be expected to slow the rate at which $\mathrm{Ca}^{2+}$ is sequestered. In addition, dialysis during whole-cell recording might lead to washout, or inactivation of calcium-binding proteins. However, microelectrode recording experiments on molluscan neurons also show slow recovery of $\left[\mathrm{Ca}^{2+}\right]_{i}$ to baseline values after $\left[\mathrm{Ca}^{2+}\right]_{\mathrm{i}}$ transients are evoked by depolarizing voltage steps, as shown by direct measurement of $\left[\mathrm{Ca}^{2+}\right]_{i}$ using an ionsensitive microclectrode, by the activation of $\mathrm{Ca}^{2+}$-dependent potassium current as an indicator of $\left[\mathrm{Ca}^{2+}\right]_{i}$, as well as by measurements of the absorbance of arsenazo III (Gorman and Thomas, $1980 \mathrm{a}$, b; Smith and Zucker, 1980; Barish and Thompson, 1983; Gorman et al., 1984; Connor et al., 1986); similar results have also been obtained in experiments on frog sympathetic neurons (Smith et al., 1983). On the other hand, during whole-cell recording the neuron is dialyzed with solutions containing a $\mathrm{Ca}^{2+}$ buffer, and this might be expected to reduce the elevation of $\left[\mathrm{Ca}^{2+}\right]_{\mathrm{i}}$ following $\mathrm{Ca}^{2+}$ influx. Surprisingly, wholecell recording experiments measuring $\mathrm{Ca}^{2+}$-dependent potassium channels show EGTA to be highly inefficient in buffering transient changes in $\left[\mathrm{Ca}^{2+}\right]_{\mathrm{i}}$ (Marty and Neher, 1985), which must underlie the usefulness of the whole-cell technique for

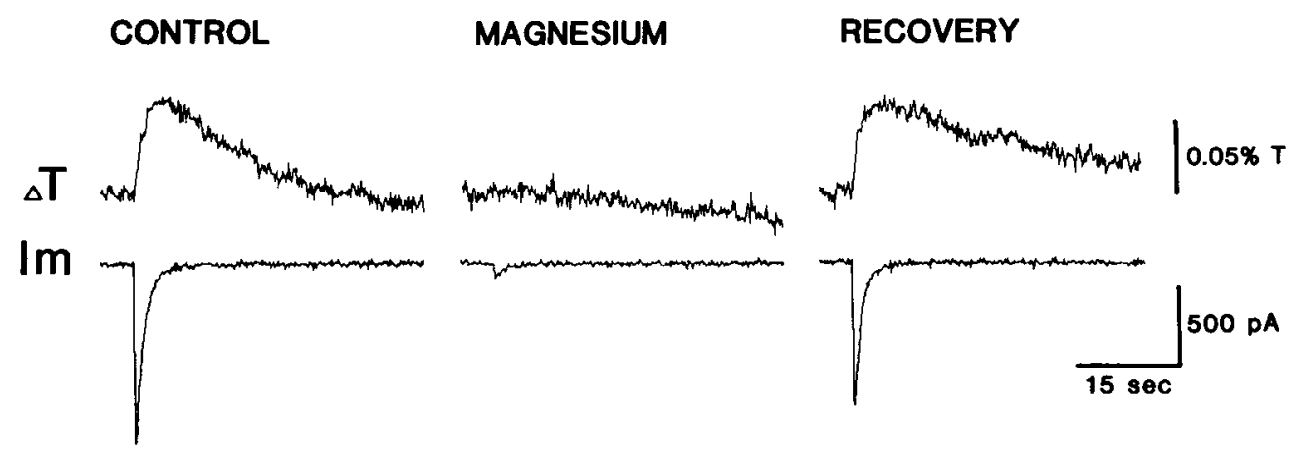

Figure 9. $\mathrm{Mg}^{2+}$ block of inward current and $\left[\mathrm{Ca}^{2+}\right]_{\mathrm{i}}$ transients evoked by NMDA-receptor activation with L-glutamate. The records show inward current and arsenazo III responses to $\mathrm{t}$-glutamate $(30 \mathrm{msec}, 1 \mathrm{~mm})$, the most potent NMDA receptor agonist characterized to date, before, during, and after brief application of $\mathrm{MgCl}_{2}$ from a puffer pipette ( $3 \mathrm{sec}, 10 \mathrm{~mm}$ in bathing medium), recorded from a spinal cord neuron voltage-clamped at $-60 \mathrm{mV}$. Block of these responses by $\mathrm{Mg}^{2+}$ is complete and reversible, suggesting an action of L-glutamate, primarily at NMDA receptors. In other neurons, application of $\mathrm{MgCl}_{2}$ blocked the arsenazo III response, with only a partial block of the inward current response; this likely reflects the mixed agonist action of L-glutamate at both NMDA and non-NMDA receptors (see Mayer and Westbrook, 1984). 
study of other $\mathrm{Ca}^{2+}$-dependent conductance mechanisms under voltage clamp (e.g., $\mathrm{Ca}^{2+}$-dependent chloride current; Marty et al., 1984; Mayer, 1985). Typically such experiments show a long period of activation of $\mathrm{Ca}^{2+}$-dependent conductance mechanisms following a depolarizing stimulus, in accord with the slowly decaying arsenazo III transients described here.

Whole-cell recording experiments also result in a rapid exchange of low-molecular-weight substances between the cytoplasm and the pipette interior. For sodium ions this occurs with a time constant of around 5 sec (Fenwick et al., 1982). Such a rapid diffusion process also might be expected to alter the time course of $\mathrm{Ca}^{2+}$ transients recorded using the whole-cell technique. However, strong buffering of $\mathrm{Ca}^{2+}$ by cellular mechanisms is likely to slow the decay of $\left[\mathrm{Ca}^{2+}\right]_{\mathrm{i}}$ transients, whereas for $\mathrm{Na}^{+}$free diffusion is more likely to occur. Despite the above considerations, the striking similarity between our results in the present experiments and those obtained during microelectrode recording from much larger molluscan neurons (Gorman and Thomas, 1980a) and from amphibian sympathetic neurons (Smith et al., 1983) suggests that, at a gross level, intracellular dialysis with the solutions used in our experiments has no major effects on calcium transients evoked by depolarizing voltage steps, at least during the initial period of recording.

\section{Calcium flux triggered by excitatory amino acids}

An increase in $\left[\mathrm{Ca}^{2+}\right]_{i}$ in response to activation of excitatory amino acid receptors on vertebrate neurons had been suggested on the basis of a number of previous observations: a significant fall in $\mathrm{Ca}^{2+}$ activity in the extracellular fluid during application of excitatory amino acids (Zanotto and Heinemann, 1983; Pumain and Heinemann, 1985; Pumain et al., 1986), direct measurements of $\left[\mathrm{Ca}^{2+}\right]_{\mathrm{i}}$ from frog motoneurons with an ion-sensitive microelectrode during depolarizing responses to L-glutamate (Bührle and Sonnhof, 1983); the $\mathrm{Ca}^{2+}$ dependence of the excitotoxic action of some amino acids (Choi, 1985); and the results of imaging studies using fura- 2 to study $\left[\mathrm{Ca}^{2+}\right]_{\mathrm{i}}$ transients in hippocampal neurons (Kudo and Ogura, 1986). In contrast to previous work, our use of voltage-clamp recording was critical to the interpretation of the present results, since it allowed us to differentiate between $\mathrm{Ca}^{2+}$ entry through voltagedependent and agonist-gated ion channels.

An important result of our work is the finding that there are different voltage sensitivities between $\mathrm{Ca}^{2+}$ influx through voltage-dependent calcium channels and NMDA-receptor channels. In the present experiments, $\mathbf{M g}^{2+}$ was present in the extracellular medium in micromolar amounts; as a result, the NMDA-evoked inward currents and arsenazo III signals peaked at $-60 \mathrm{mV}$ and declined with further hyperpolarization because of channel block by $\mathrm{Mg}^{2+}$ (Mayer et al., 1984; Nowak et al., 1984). Under physiological conditions, with $1 \mathrm{~mm}$ extracellular $\mathrm{Mg}^{2+}$, block of NMDA-receptor channels confers a higher degree of voltage sensitivity, such that the NMDA-activated inward current peaks at around $-30 \mathrm{mV}$, and declines with hyperpolarization (e.g., Mayer et al., 1984; Nowak et al., 1984; Mayer and Westbrook, 1985a). $\mathrm{Ca}^{2+}$ influx through NMDA-receptor channels should parallel this current-voltage relationship, and thus may be significant at the resting potential. Indeed, recent observations demonstrating NMDA-receptor-mediated components of EPSPs, with physiological concentrations of $\mathrm{Mg}^{2+}$ in the extracellular fluid (Thomson et al., 1985; Hablitz and Langmoen, 1986; Thomson, 1986) support the concept of activation of
A

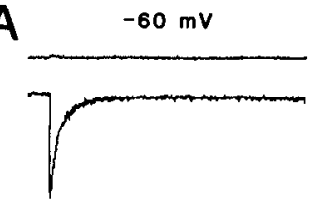

B $-30 \mathrm{mV}$
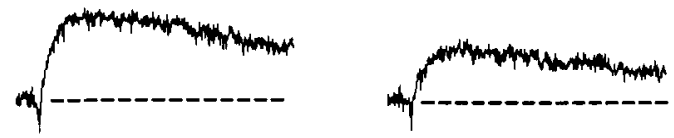

C

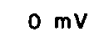

D

$60 \mathrm{mV}$
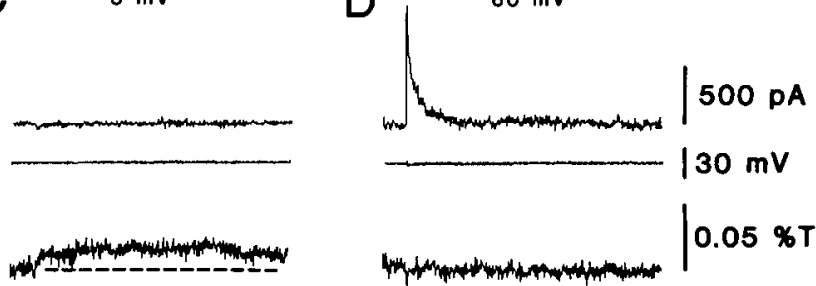

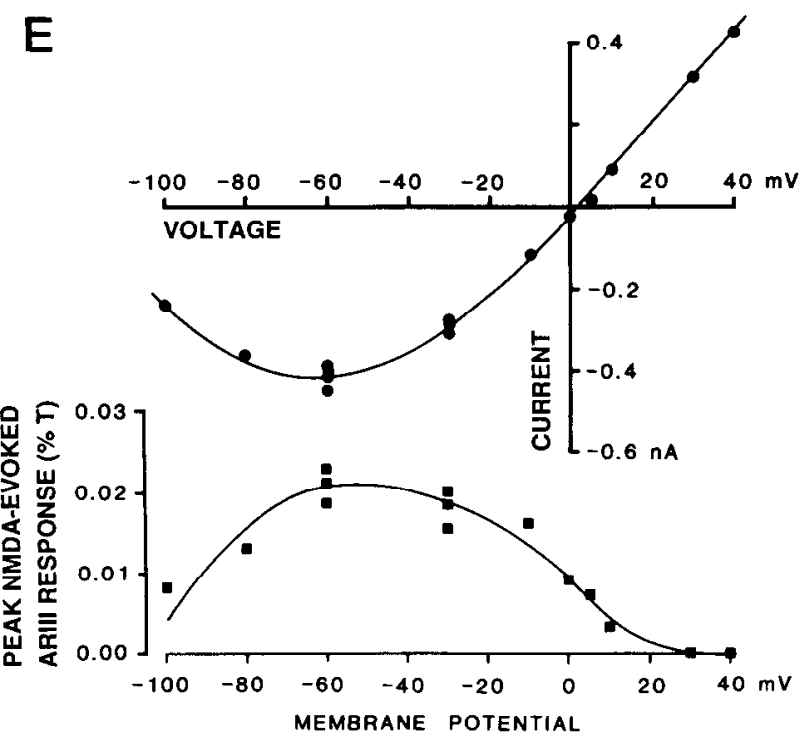

Figure 10. Voltage dependence of $\mathrm{Ca}^{2+}$ flux through NMDA-receptor channels. $A-D$, Examples of responses to a constant dose of NMDA (100 msec, $1 \mathrm{~mm}$ ) applied to a spinal cord neuron voltage-clamped at membrane potentials of -60 to $+60 \mathrm{mV}$. Note the $\left[\mathrm{Ca}^{2+}\right]_{\mathrm{i}}$ transient response recorded at $0 \mathrm{mV}$, the NMDA reversal potential. $E$, Similar data obtained from another spinal cord neuron and plotted as peak current versus voltage (upper graph) and peak arsenazo III response versus voltage (lower graph); similar responses were obtained in 3 neurons. The fall in response amplitude on membrane hyperpolarization negative to $-60 \mathrm{mV}$ reflects block of NMDA-receptor channels by residual micromolar $\mathrm{Mg}^{2+}$ in the extracellular fluid (Mayer and Westbrook, 1985a).

NMDA receptors close to the resting potential. Furthermore, $\mathrm{Mg}^{2+}$ is necessary for the NMDA-activated pacemaker activity seen in lamprey spinal cord (Grillner and Wallén, 1985).

In contrast to $\mathrm{Ca}^{2+}$ influx through NMDA-receptor channels, peak calcium current through type $\mathrm{L}$ and type $\mathrm{N}$ voltage-dependent calcium channels is recorded at membrane potentials close to $+10 \mathrm{mV}$ (Nowycky et al., 1985), similar to our observations with arsenazo III. In addition, the relatively depolarized threshold for activation of types $\mathrm{L}$ and $\mathrm{N}$ calcium channels 
Figure 11. Down-regulation of NMDA activated inward current during elevation of $\left[\mathrm{Ca}^{2+}\right]_{i}, A$, Voltage protocol and absorbance trace $(570-660$ nm) used to raise $\left[\mathrm{Ca}^{2+}\right]_{i}$, and the time of application of NMDA during the test response. $B$, Control, test, and recovery of inward current responses to NMDA. These responses were recorded from a spinal cord neuron 22-32 min after the start of whole-cell recording, after much of the $\mathrm{Ca}^{2+}$ conductance had washed out; the rise in $\left[\mathrm{Ca}^{2+}\right]$, evoked by a similar voltage protocol earlier in the recording period would have been much larger.
Figure 12. $A-C$, Paired $\left[\mathrm{Ca}^{2++}\right]_{\text {i }}$ transients (recorded as $570-660 \mathrm{~nm}$ ) evoked by voltage steps (upper traces) and application of NMDA ( $250 \mathrm{msec}, 1 \mathrm{~mm}$; lower traces), at various times after the start of whole-cell recording from a single spinal neuron voltage-clamped at $-60 \mathrm{mV}$. Voltage steps were from -60 to $0 \mathrm{mV}$ for $1.0 \mathrm{sec}$, and decay of the resulting $\left[\mathrm{Ca}^{2+}\right]_{\text {; }}$ transient is fitted by 2 exponentials of time constants $1-4$ and 10-20 scc. These are shown as dashed lines, and their sum is plotted as a solid line superimposed on the raw data. The area under each of the exponentials was calculated by integration over the period $0-32 \mathrm{sec}$, using the time constants obtained by curve-fitting. The $\left[\mathrm{Ca}^{2+}\right]_{\mathrm{i}}$ transient evoked by NMDA is recorded at higher gain, and has been smoothed using a 3-point moving average. $D$, Plot of the peak amplitude of the NMDAevoked $\left[\mathrm{Ca}^{2+}\right]_{\text {i }}$ transient response versus the integral of the slowly decaying component of the $\left[\mathrm{Ca}^{2+}\right]_{i}$ transient response evoked by voltage steps. The line is a regression fit $(r=0.93)$. Responses were recorded using a patch solution containing ATP to slow rundown of $\mathrm{Ca}^{2+}$ currents.
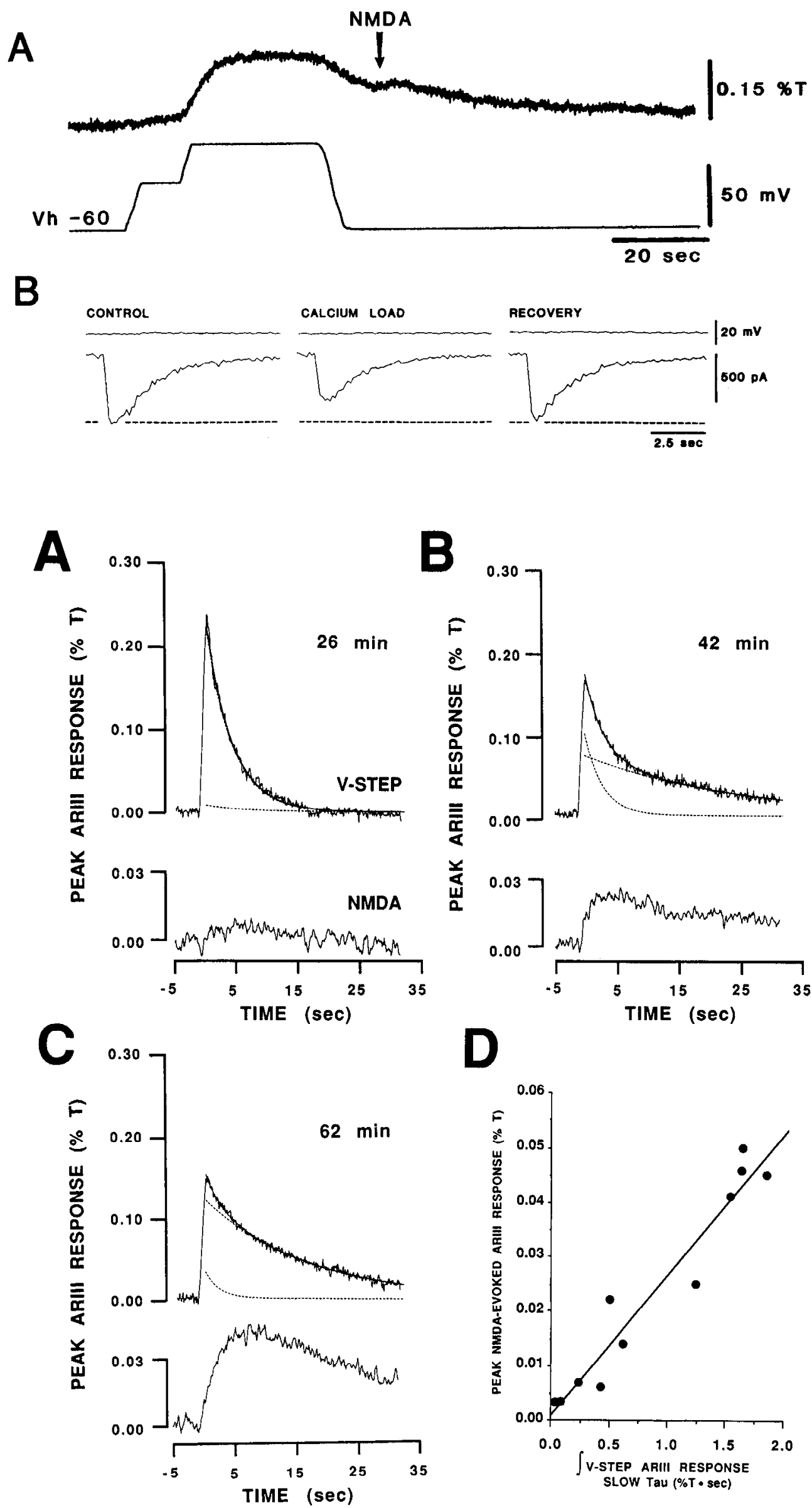

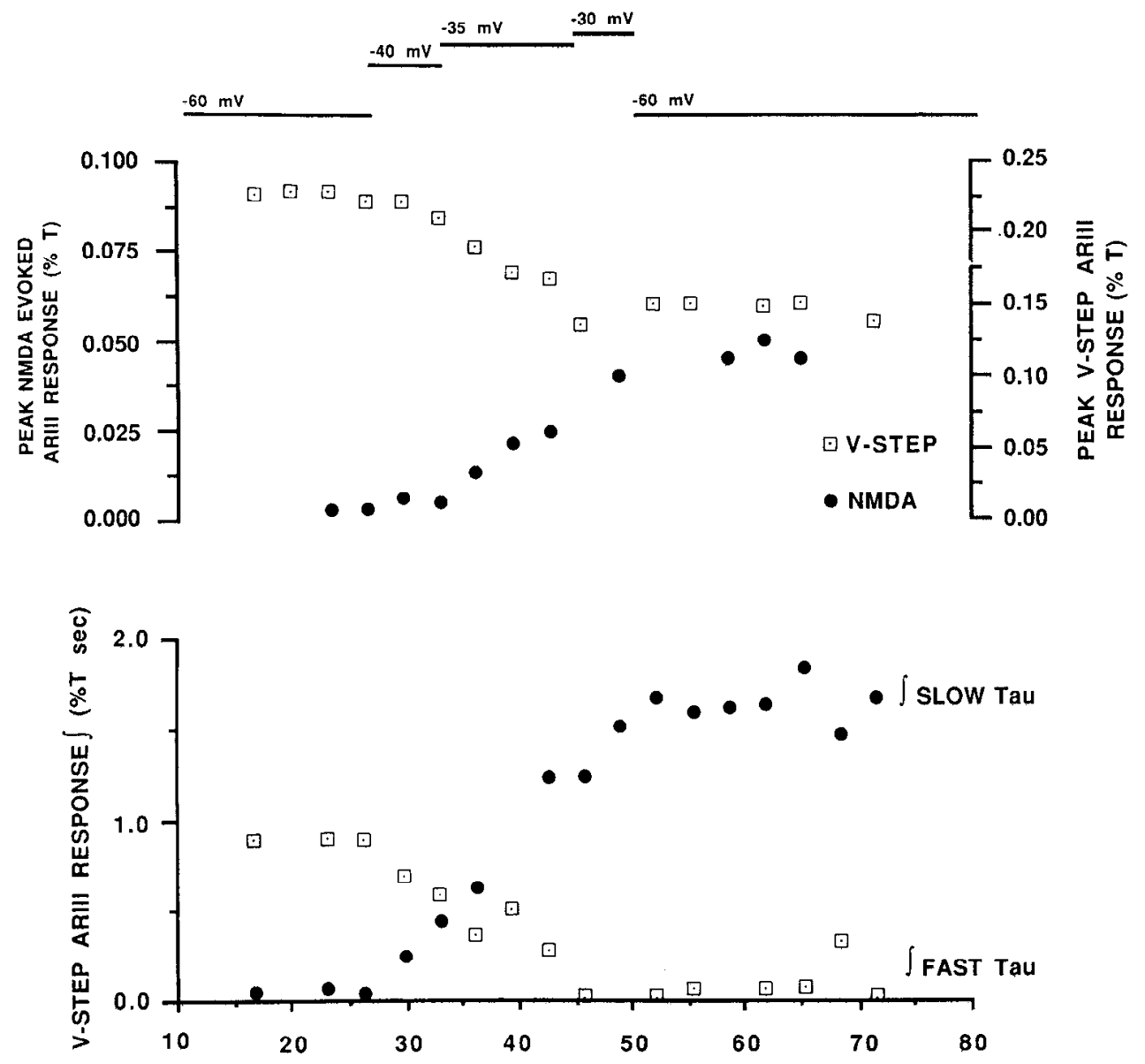

TIME SINCE START OF WHOLE CELL RECORDING (mins)

Figure 13. Plot of the data obtained by analysis of responses to voltage jumps and application of NMDA at various times after the start of wholecell recording, examples of which are presented in Figure 12. During the experiment the holding potential was shifted over the range -60 to -30 $\mathrm{mV}$, as illustrated in the upper portion of the figure. The top set of data points shows the peak amplitude of the NMDA- and voltage step-evoked $\left[\mathrm{Ca}^{2+}\right]$, transients as a function of time after the start of whole-cell recording (note the different amplitude scales). The lower set of data points shows a plot of the integrals of the fast and slowly decaying components of the response to voltage steps (as shown in Fig. 12) as a function of time after the start of whole-cell recording. Following $\mathrm{Ca}^{2 *}$ loading evoked by holding the membrane potential for several minutes at the threshold for $\mathrm{Ca}^{2+}$ entry $(-35$ to $-30 \mathrm{mV})$, there is a progressive increase in the amplitude of the $\left[\mathrm{Ca}^{2+}\right.$, transient evoked by NMDA, and a switch from a fast to slow clearance process for recovery to baseline values of $\left[\mathrm{Ca}^{2+}\right]$. During the period of this experiment, the baseline absorbance $(570-660 \mathrm{~nm})$ remained constant until the membrane potential was depolarized to $-30 \mathrm{mV}$, whereupon $\left[\mathrm{Ca}^{2+}\right]$ increased at a slow but constant rate during the $180 \mathrm{sec}$ period of clamp at $-30 \mathrm{mV}$; the peak rise in absorbance during clamp at $-30 \mathrm{mV}$ was $122 \%$ that of the amplitude of the initial transient response plotted in Figure 12, and showed complete recovery to baseline in the $12 \mathrm{~min}$ period following return to $-60 \mathrm{mV}$. Note, however, that decay of the $\left[\mathrm{Ca}^{2-}\right]$, transient response in response to voltage steps shows no recovery to the faster clearance process for the remainder of the experiment, suggesting that $\mathrm{Ca}^{2}$ loading had either inactivated or saturated the process underlying fast clearance.

(around $-30 \mathrm{mV}$ ) suggests that activation of NMDA receptors will allow $\mathrm{Ca}^{2+}$ influx at membrane potentials considerably hyperpolarized to that required for significant activation of calcium channels. NMDA-evoked pacemaker-like activity in lamprey spinal motoneurons is both $\mathrm{Ca}^{2+}$ - and $\mathrm{Mg}^{2+}$-dependent (Grillner and Wallén, 1985), and appears to occur at membrane potentials intermediate between those required for activation of type $\mathrm{L}$ and type $\mathrm{N}$ calcium channels and deinactivation of type T calcium channels (Nowycky et al., 1985), suggesting that the voltage-dependent $\mathrm{Ca}^{2+}$ flux through NMDA-receptor channels might contribute significantly to the rise in $\left[\mathrm{Ca}^{2+}\right]_{1}$ required for activation of $\mathrm{Ca}^{2+}$-dependent potassium current, and the subsequent hyperpolarizing phase of the pacemaker cycle.

\section{Implications for synaptic transmission}

Arsenazo III has also been used to demonstrate calcium flux through ion channels linked to L-glutamate receptors on post- synaptic axons in the squid giant synapse (Eusebi et al., 1985), and through nicotinic acetylcholine receptors at the frog neuromuscular junction (Miledi et al., 1980). Calcium flux through L-glutamate-sensitive receptors during transmission at the locust neuromuscular junction has also been demonstrated by recording miniature junctional currents with $\mathrm{Ca}^{2+}$ as the only permeant cation in the extracellular fluid (Cull-Candy and Miledi, 1982). However NMDA-receptor channels appear to be unique in their relatively high $\mathrm{Ca}^{2+}$ permeability (Mayer and Westbrook, 1987b), coupled with voltage sensitivity imposed by the channel-blocking action of $\mathrm{Mg}^{2+}$. The combination of these 2 properties may underlie the regulation by NMDA-receptors of long-lasting changes in neuronal excitability in brain areas such as the hippocampus.

Several years ago, Baudry and Lynch proposed that induction of LTP resulted from activation of an excitatory amino acid receptor, followed by an increase in cytoplasmic free calcium, 
which then acted as a second messenger to induce the necessary long-term changes in synaptic efficacy (Baudry and Lynch, 1980; Lynch and Baudry, 1984). Our results provide direct evidence for an excitatory amino acid-receptor-triggered rise in $\left[\mathrm{Ca}^{2+}\right]_{i}$. Several other lines of evidence are consistent with this, i.e., block of LTP by intracellular injection of the $\mathrm{Ca}^{2+}$ chelator EGTA (Lynch et al., 1983) and induction of LTP on raising $\left[\mathrm{Ca}^{2+}\right]_{0}$ (Turner et al., 1982). Also of interest in this regard was the discovery that highly specific NMDA-receptor antagonists block the induction of LTP with no apparent effect on fast excitatory synaptic transmission between Schaeffer collaterals and CA1 neurons (Collingridge et al., 1983; Harris et al., 1984). $\mathrm{Ca}^{2+}$ flux through NMDA-receptor channels could link these 2 sets of observations in providing a direct source of $\mathrm{Ca}^{2+}$ necessary for the induction of LTP (however, see Harris and Cotman, 1986). It is interesting to note that several recent studies have demonstrated modulation of LTP by changes in postsynaptic membrane potential: depolarizing electronic potentials applied synchronously with presynaptic stimulation activate an LTP-like process (conjunctive stimulation; Kelso et al., 1986; Wigström et al., 1986); and by contrast use of voltage clamp during synaptic stimulation to prevent membrane potential depolarization (Kelso et al., 1986), or membrane potential hyperpolarization during synaptic stimulation (Malinow and Miller, 1986) blocks the induction of LTP. These results are consistent with the hypothesis that membrane potential depolarization during synaptic excitation is required to relieve $\mathrm{Mg}^{2+}$ block of NMDAreceptor channels. Subsequent calcium flux through NMDAreceptor channels, then, triggers processes leading to induction of LTP.

Another area of interest concerning $\mathrm{Ca}^{2+}$ flux through NMDAreceptor channels derives from studies of the excitotoxic action of L-glutamate and its analogs. In particular, observations that the anesthetic ketamine, a selective antagonist of responses to NMDA (Anis et al., 1983), prevents anoxia-evoked neuronal degeneration in dissociated cultures (Weiss et al., 1986), as do competitive NMDA-receptor antagonists in vivo (Simon et al., 1984; Wieloch, 1985), together with the results of ion-substitution experiments demonstrating the $\mathrm{Ca}^{2+}$ dependence of such excitotoxicity (Choi, 1985; Garthwaite et al., 1986) suggest that elevation of $\left[\mathrm{Ca}^{2+}\right]_{i}$ is linked to activation of NMDA receptors during pathophysiological processes (see Mayer and Westbrook, 1987c). The clinical significance of this result has yet to be determined, but potentially the block of NMDA-receptor channels seems a promising therapy for preventing nerve cell damage resulting from anoxic episodes.

Our results do not allow quantitative analysis of the relative $\mathrm{Ca}^{2+}$ permeabilities of the conductance mechanisms linked to the various excitatory amino acid-receptor subtypes, but do suggest a considerable difference between ion flux through channels linked to NMDA and non-NMDA receptors. Reversalpotential measurements confirm this difference between the conductance mechanisms activated by kainate and NMDA and show negligible $\mathrm{Ca}^{2+}$ permeability of the conductance mechanism linked to kainate receptors, whereas for NMDA receptors $P_{\mathrm{Ca}}: P_{\mathrm{Na}}$ is $\gg 1$ (see Mayer and Westbrook, $1985 \mathrm{~b}, 1987 \mathrm{~b}$ MacDermott et al., 1986). In summary, our results suggest that the rise in $\left[\mathrm{Ca}^{2+}\right]_{i}$ recorded during activation of NMDA receptors is a direct result of $\mathrm{Ca}^{2+}$ flux through receptor-activated ion channels rather than of release from intracellular stores, on the basis of the voltage dependence of the arsenazo III response to NMDA, either during depolarization towards the $\mathrm{Ca}^{2+}$ equilib- rium potential or during hyperpolarization to evoke $\mathrm{Mg}^{2+}-$ sensitive channel block.

Calcium indicators are likely to provide additional interesting information on the role of $\mathrm{Ca}^{2+}$ fluxes linked to NMDA-receptor activation. High-resolution imaging studies will be useful to determine sites of especially high $\mathrm{Ca}^{2+}$ flux; in particular, it will be interesting to know whether $\mathrm{Ca}^{2+}$ influx occurs in dendritic spines, and whether regulation of $\left[\mathrm{Ca}^{2+}\right]_{i}$ at these sites differs from that in the bulk cytoplasm. For example, clustering of NMDA-receptor channels into functional domains might provide a mechanism for generating localized areas of high $\mathrm{Ca}^{2+}$ flux, as has been suggested for voltage-sensitive $\mathrm{Ca}^{2+}$ channels (Fogelson and Zucker, 1985).

\section{References}

Adams, D. J., T. M. Dwyer, and B. Hille (1980) The permeability of endplate channels to monovalent and divalent cations. J. Gen. Physiol. 75: 493-510.

Adams, P. R. (1975) A study of desensitisation using voltage clamp. Pीügers Arch. 360: 135-144.

Almers, W., and E. Neher (1985) The Ca signal from fura-2 loaded mast cells depends strongly on the method of dye-loading. FEBS Lett. 192: 13-18.

Anis, N. A., S. C. Berry, N. R. Burton, and D. Hodge (1983) The dissociative anaesthetics, ketamine, and phencyclidine, selectively reduce excitation of central mammalian neurones by $\mathrm{N}$-methyl-aspartate. Brit. J. Pharmacol. 79: 565-575.

Baker, P. F., and W. W. Schlaepfer (1978) Uptake and binding of calcium by axoplasm isolated from giant axons of Loligo and Myxicola. J. Physiol. (Lond.) 276: 103-125.

Barish, M. E., and S. H. Thompson (1983) Calcium buffering and slow recovery kinetics of calcium-dependent outward current in molluscan neurones. J. Physiol. (Lond.) 337: 201-219.

Baudry, M., and G. Lynch (1980) Hypothesis regarding the cellular mechanisms responsible for long-term potentiation in the hippocampus. Exp. Neurol. 68: 202-204.

Berridge, M. J., and R. F. Irvine (1984) Inositol trisphosphate, a novel second messenger in cellular signal transduction. Nature 312: 315321.

Blaustein, M. P. (1974) The interrelationship between sodium and calcium fluxes across cell membranes. Rev. Physiol. Biochem. Exp. Pharmacol. 70: 33-82.

Bolsover, S. R. (1986) Two components of voltage-dependent calcium influx in mouse neuroblastoma cells. J. Gen. Physiol. 88:149-165.

Brodin, L., and S. Grillner (1985) The role of excitatory amino acid induced neurotransmitters in the initiation of locomotion in the lamprey spinal cord. I. The effects of excitatory amino acid antagonists. Brain Res. 360: 139-148.

Brown, T.H., and D. Johnston (1983) Voltage clamp analysis of mossy fiber synaptic input to hippocampal neurons. J. Neurophysiol. 50: 487-507.

Bürhle, C. P., and U. Sonnhof (1983) The ionic mechanism of the excitatory action of L-glutamate upon the membranes of motoneurones of the frog. Pflügers Arch. 396: 154-162.

Choi, D. (1985) Glutamate neurotoxicity in cortical cell culture is calcium dependent. Neurosci. Lett. 58: 293-297.

Collingridge, G. L., S. J. Kehl, and H. McLennan (1983) Excitatory amino acids in synaptic transmission in the Schaffer collateral-commissural pathway of the rat hippocampus. J. Physiol. (Lond.) 334: 33-46.

Connor, J. A., R. Kretz, and E. Shapiro (1986) Calcium levels measured in a presynaptic neurone of Aplysia under conditions that modulate transmitter release. J. Physiol. (Lond.) 375: 625-642.

Cull-Candy, S. G., and R. Miledi (1982) Properties of miniature excitatory junctional currents at the locust nerve-muscle junction. $J$. Physiol. (Lond.) 326: 527-551.

Cull-Candy, S. G., and M. M. Usowicz (1987) Multiple-conductance channels activated by excitatory amino acids in cerebellar neurons. Nature 325: 525-528.

Dale, N., and A. Roberts (1984) Excitatory amino acid receptors in Xenopus embryo spinal cord and their role in the activation of swimming. J. Physiol. (Lond.) 348: 527-543. 
Dale, N., and A. Roberts (1985) Dual-component amino acid-mediated synaptic potentials: Excitatory drive for swimming in Xenopus embryos. J. Physiol. (Lond.) 363: 35-59.

Dunwiddie, T., and G. Lynch (1979) The relationship between extracellular calcium concentrations and the induction of hippocampal long-term potentiation. Brain Res. 169: 103-110.

Engberg, I., and K. C. Marshall (1979) Reversal potential for 1a excitatory post synpatic potentials in spinal motoneurons of cats. Neuroscience 4: 1583-1591.

Eusebi, F., R. Miledi, I. Parker, and J. Stinnaker (1985) Post-synaptic calcium influx at the giant synapse of the squid during activation by L-glutamate. J. Physiol. (Lond.) 369: 183-197.

Fatt, P., and B. Katz (1951) An analysis of the end-plate potential recorded with an intra-cellular electrode J. Physiol. (Lond.) 115:320370.

Fenwick, E. M., A. Marty, and E. Neher (1982) Sodium and calcium channels in bovine chromaffin cells. J. Physiol. (Lond.) 331: 599635.

Filliben, J. J. (1984) Dataplot-introduction and overview. National Bureau of Standards, Special Publication 667.

Fogelson, A. A., and R. S. Zucker (1985) Presynaptic calcium diffusion from various arrays of single channels. Biophys. J. 48: 1003-1017.

Forscher, P., and G. S. Oxford (1985) Modulation of calcium channels by norepinephrine in internally dialyzed avian sensory neurons. $J$. Gen. Physiol. 85: 743-763.

Forsythe, I. D., and G. L. Westbrook (1986) Monosynaptic activation of NMDA receptors in mouse spinal cord cultures. Soc. Neurosci. Abstr. 12: 62

Gage, P. W., and D. Van Helden (1979) Effects of permeant monovalent cations on end-plate channels. J. Physiol. (Lond.) 288: 509528.

Garthwaite, G., F. Ilajós, and J. Garthwaite (1986) Ionic requirements for neurotoxic effects of excitatory amino acid analogues in rat cerebellar slices. Neuroscience 18: 437-447.

Gorman, A. L. F., and M. V. Thomas (1980a) Intracellular calcium accumulation during depolarization in a molluscan neurone. J. Physiol. (Lond.) 308: 259-285.

Gorman, A. L. F., and M. V. Thomas (1980b) Potassium conductance and internal calcium accumulation in a molluscan neurone. J. Physiol. (Lond.) 308: 287-313.

Gorman, A. L. F., A. Herman, and M. V. Thomas (1981) Intracellular calcium and the control of neuronal pacemaker activity. Fed. Proc. 40: 2233-2239.

Gorman, A. L. F., S. Levy, E. Nasi, and D. Tillotson (1984) Intracellular calcium measured with calcium-sensitive micro-electrodes and arsenazo III in voltagc-clamped Aplysia ncuroncs. J. Physiol. (Lond.) 353: 127-142.

Grillner, S., and P. Wallén (1985) The ionic mechanisms underlying $N$-methyl-D-aspartate receptor-induced, tetrodotoxin-resistant membrane potential oscillations in lamprey neurons active during locomotion. Neurosci. Lett 60: 289-294.

Hablitz, J. J., and I. A. Langmoen (1986) N-methyl-D-aspartate receptor antagonists reduce synaptic excitation in the hippocampus. $\mathrm{J}$. Neurosci. 6: 102-106.

Harris, E. W., and C. W. Cotman (1986) Long-term potentiation of guinea pig mossy fiber responses is not blocked by $N$-methyl-D-aspartate antagonists. Neurosci. Lett. 70: 132-137.

Harris, E. W., A. H. Ganong, and C. W. Cotman (1984) Long-term potentiation in the hippocampus involves activation of $N$-methyl-Daspartate receptors. Brain Res. 323: 132-137.

Jahr, C. E., and C. F. Stevens (1987) Glutamate activates multiple single channel conductances in hippocampal neurons. Nature 325 : 522-525.

Katz, B., and R. Miledi (1965) The effect of calcium on acetylcholine release from motor nerve terminals. Proc. R. Soc. Lond [Biol.] 161: 496-503.

Katz, B., and R. Miledi (1967) The timing of calcium action during neuromuscular transmission. J. Physiol. (Lond.) 189: 535-544.

Kelso, S. R., A. H. Ganong, and T. H. Brown (1986) Hebbian synapses in hippocampus. Proc. Natl. Acad. Sci. USA 83: 5326-5330.

Kostyuk, P. G., N. S. Veselovsky, and S. A. Fedulova (1981) Ionic currents in the somatic membrane of rat dorsal root ganglion neurons. II. Calcium currents. Neuroscience 6: 2431-2437.

Kudo, Y., and A. Ogura (1986) Glutamate-induced increase in intracellular $\mathrm{Ca}^{2+}$ concentration in isolated hippocampal neurones. $\mathrm{Br}$. J. Pharmacol. 89: 191-198.
Lewis, C. A. (1979) Ion-concentration dependence of the reversal potential and the single channel conductance of ion channels at the frog neuromuscular junction. J. Physiol. (Lond.) 286: 417-445.

Lynch, G., and M. Baudry (1984) The biochemistry of memory: A new and specific hypothesis. Science 224: 1057-1063.

Lynch, G., J. Larson, S. Kelso, G. Barrionuevo, and F. Schottler (1983) Intracellular injections of EGTA block induction of hippocampal long-term potentiation. Nature 305: 719-721.

MacDermott, A. B., M. L. Maver, G. L. Westbrook, S. J. Smith, and J. L. Barker (1986) NMDA-receptor activation increases cytoplasmic calcium concentration in cultured spinal cord neurones. Nature 321: 519-522.

Malinow, R., and J. P. Miller (1986) Postsynaptic hyperpolarization during conditioning reversibly blocks induction of long-term potentiation. Nature $320: 529-530$.

Marty, A., and E. Neher (1985) Potassium channels in cultured bovine adrenal chromaffin cells. J. Physiol. (Lond.) 367: 117-141.

Marty, A., Y. P. Tan, and A. Trautmann (1984) Three types of calcium-dependent channel in rat lacrimal glands. J. Physiol. (Lond.) 357: 293-325

Mayer, M. L. (1985) A calcium-activated chloride current generates the after-depolarization of rat sensory neurones in culture. J. Physiol. (Lond.) 364: 217-239.

Mayer, M. L., and G. L. Westbrook (1984) Mixed-agonist action of excitatory amino acids on mouse spinal cord neurons under voltage clamp. J. Physiol. (Lond.) 354: 29-53.

Mayer, M. L., and G. L. Westbrook (1985a) The action of $N$-methylD-aspartic acid on mouse spinal neurons in culture. J. Physiol. (Lond.) 361: 65-90.

Mayer, M. L., and G. L. Westbrook (1985b) Divalent cation permeability of $N$-methyl-D-aspartate channels. Soc. Neurosci. Abstr. 11: 785.

Mayer, M. L., and G. L. Westbrook (1987a) The physiology of excitatory amino acids in the vertebrate central nervous system. Prog. Neurobiol. 28: 197-276.

Mayer, M. L., and G. L. Westbrook (1987b) Permeation and block of $N$-methyl-D-aspartate receptor-channels by divalent cations in mouse cultured central neurones. J. Physiol. (Lond.) (in press).

Mayer, M. L., and G. L. Westbrook (1987c) Cellular mechanisms underlying excitotoxicity. Trends Neurosci. 10:59-61.

Mayer, M. L., G. L. Westbrook, and P. B. Guthrie (1984) Voltagedependent block by $\mathrm{Mg}^{2+}$ of NMDA responses in spinal cord neurones. Nature 309: 261-263.

Miledi, R. (1980) Intracellular calcium and desensitisation of acetylcholine receptors. Proc. R. Soc. Lond. [Biol.] 209: 447-452.

Miledi, R., I. Parker, and G. Schalow (1980) Transmitter induccd calcium entry across the post-synaptic membrane at frog end-plates measured using arsenazo III. J. Physiol. (Lond.) 300: 197-212.

Neale, E. A., M. L. Mayer, and L. M. Bowers (1986) Sensory neuron ultrastructure following whole cell patch recording. Soc. Neurosci. Abstr. 12: 1199

Nicoletti, F., J. L. Meek, M. J. Iadarola, D. M. Chuang, B. L. Roth, and E. Costa (1986) Coupling of inositol phospholipid metabolism with excitatory amino acid recognition sites in rat hippocampus. $J$. Neurochem. 46: 40-46.

Nowak, L., P. Bregestovski, P. Ascher, A. Herbet, and A. Prochiantz (1984) Magnesium gates glutamate activated channels in mouse central neurones. Nature 307: 462-465.

Nowycky, M. C., A. P. Fox, and R. W. Tsien (1985) Three types of neuronal calcium channel with different calcium agonist sensitivity. Nature 316: 440-443.

Olverman, H. J., A. W. Jones, and J. C. Watkins (1984) L-Glutamate has a higher affinity than other amino acids for $\left[{ }^{3} \mathrm{H}\right]$-D-AP5 binding sites in rat brain membranes. Nature $307: 460-462$.

Pumain, R., and U. Heinemann (1985) Stimulus- and amino acidinduced calcium and potassium changes in the rat neocortex. J. Neurophysiol. 53: 1-16.

Pumain, R., J. Louvel, and I. Kurcewicz (1986) Long-term alterations in amino acid induced ionic conductances in chronic epilepsy. In Excitatory Amino Acids and Epilepsy, R. Schwarcz and Y. Ben-Ari, eds., pp. 439-447, Plenum, New York.

Rothman, S. M., and J. W. Olney (1986) Glutamate and the pathophysiology of hypoxic-ischemic brain damage. Ann. Neurol. 19: 105111

Schoffelmeer, A. M. N., and A. H. Mulder (1983) [ $\left.{ }^{3} \mathrm{H}\right]$ Noradrenaline release from brain slices induced by an increase in the intracellular 
sodium concentration: Role of intracellular calcium stores. J. Neurochem. 40: 615-621.

Scubon-Mulieri, B., and R. L. Parsons (1977) Desensitisation and recovery at the frog neuromuscular junction. J. Gen. Physiol. 69: 431447.

Simon, R. P., J. H. Swan, T. Griffiths, and B. S. Meldrum (1984) Blockade of $N$-methyl-D-aspartate receptors may protect against ischemic damage in the brain. Science 226: 850-852.

Sladeczek, F., J. P. Pin, M. Récasens, J. Bockaert, and S. Weiss (1985) Glutamate stimulates inositol phosphate formation in striatal neurones. Nature 317: 717-719.

Smith, S. J. (1980) $\mathrm{Ca}^{2+}$ regulation in gastropod nerve cell bodies. In Cold Spring Harbor Reports in the Neurosciences. 1: Molluscan Nerve Cells: From Biophysics to Behaviour, J. Koester and J. H. Byrne, eds., pp. 81-91, Cold Spring Harbor, New York.

Smith, S. J. (1986) Polychromator for recording optical absorbance changes from single cells. In Optical Methods in Cell Physiology, P. De Weer and B. M. Salzberg, eds., pp. 255-260, Wiley, New York.

Smith, S. J., and R. S. Zucker (1980) Aequorin response facilitation and intracellular calcium accumulation in molluscan neurones. $\mathrm{J}$. Physiol. (Lond.) 300: 167-196.

Smith, S. J., A: B. MacDermott, and F. F. Weight (1983) Detection of intracellular $\mathrm{Ca}^{2+}$ transients in sympathetic neurones using arsenazo III. Nature 304: 350-352.

Takeuchi, A., and N. Takeuchi (1960) On the permeability of endplate membrane during the action of transmitter. J. Physiol. (Lond.) 154: 52-67.

Thomson, A. M. (1986) A magnesium-sensitive post-synaptic potential in rat cerebral cortex resembles responses to $N$-methylaspartate. J. Physiol. (Lond.) 370: 531-549.

Thomson, A. M., D. C. West, and D. Lodge (1985) A $N$-methylaspartate receptor-mediated by synapse in rat cerebral cortex: A site of action of ketamine? Nature 313: 479-481.

Turner, R. W., K. G. Baimbridge, and J. J. Miller (1982) Calciuminduced long-term potentiation in the hippocampus. Neuroscience 7 : 1411-1416.
Watkins, J. C., and R. H. Evans (1981) Excitatory amino acid transmitters. Ann. Rev. Pharmacol. Toxicol. 21: 165-204.

Weiss, J., M. P. Goldberg, and D. W. Choi (1986) Ketamine protects cultured neocortical neurons from hypoxic injury. Brain Res. 380: $186-190$.

Westbrook, G. L., and M. L. Mayer (1984) Glutamate currents in mammalian spinal neurones: Resolution of a paradox. Brain Res. 301: 375-379.

Westbrook, G. L., and M. L. Mayer (1986) The membrane action of excitatory amino acids on cultured mouse spinal cord neurons. In Excitatory Amino Acids and Epilepsy, R. Schwarcz and Y. Ben-Ari, eds., pp. 497-506, Plenum, New York.

Westbrook, G. L., M. L. Mayer, M. A. A. Namboodiri, and J. H. Neale (1986) High concentrations of $N$-acetylaspartylglutamate (NAAG) selectively activate NMDA receptors on mouse spinal cord neurons in cell culture. J. Neurosci. 6: 3385-3392.

Wieloch, T. (1985) Hypoglycaemia-induced neuronal damage prevented by an $N$-methyl-D-aspartate antagonist. Science 230:681-683.

Wigström, H., and B. Gustafsson (1984) A possible correlate of the postsynaptic condition for long-lasting potentiation in the guinea pig hippocampus in vitro. Neurosci. Lett. 44: 327-332.

Wigström, H., J. H. Swann, and P. Andersen (1979) Calcium dependency of synaptic long-lasting potentiation in the hippocampal slice. Acta Physiol. Scand. 105: 126-128.

Wigström, H., B. Gustafsson, and Y. Huang (1985) A synaptic potential following single volleys in the hippocampal CAl region possibly involved in the induction of long-lasting potentiation. Acta Physiol. Scand. 124: 475-478.

Wigström, H., B. Gustafsson, Y. Huang, and W. C. Abraham (1986) Hippocampal long-term potentiation is induced by pairing single afferent volleys with intracellularly injected current pulses. Acta Physiol. Scand. 126: 317-319.

Zanotto, L., and U. Heinemann (1983) Aspartate and glutamate induced reductions in extracellular free calcium and sodium concentration in area CA1 of 'in vitro' hippocampal slices of rats. Neurosci. Lett. 35: 79-84. 